Accepted for publication to the Academy of Management Discoveries. https://journals.aom.org/doi/10.5465/amd.2020.0075

\title{
Scouting and Schmoozing: A Gender Difference in Networking during Job Search
}

\author{
Elena Obukhova \\ McGill University \\ Desautels Faculty of Management \\ 1001 rue Sherbrooke Ouest \\ Montreal, Quebec \\ Canada H3A 1G5 \\ +1 (514) 8933-896 \\ elena.obukhova@mcgill.ca
}

\author{
Adam M. Kleinbaum \\ Dartmouth College \\ Tuck School of Business \\ 100 Tuck Hall \\ Hanover, NH 03755 USA \\ +1 (603) 646-6447 \\ adam.m.kleinbaum@tuck.dartmouth.edu
}

Acknowledgements: This paper benefitted from discussions with and comments from Emily Bianchi, Dan Cable, Tiziana Casciaro, Lisa Cohen, Daphne Demetry, Laura Doerring, Gina Dokko, Roberto Fernandez, Isabel Fernandez-Mateo, Connie Helfat, Matissa Hollister, Martin Kilduff, Jen Merluzzi, Siobhan O’Mahony, Brian Rubineau, Sandra Smith, Wendy Smith, Olav Sorenson, Adina Sterling, and Peter Younkin; seminar participants at HEC Paris, London Business School, the University of Chicago, Yale University, Stanford University and Santa Clara University, and students in the Tuck Social Networks in Organizations seminar; and conference participants at the Stanford Hiring and Organizations Conference, the European Group for Organizational Studies, the Junior Faculty Workshop in Organization Theory, the Academy of Management annual meetings, and the Sunbelt Social Networks conference. We also acknowledge financial support form McGill Internal Social Sciences and Humanities Development Grant to Elena Obukhova and the many and various staff members at the university studied for their support of the data collection. The usual disclaimer applies.

Keywords: Networking; social networks; gender; job search; mixed-methods. 


\section{Scouting and Schmoozing: A Gender Difference in Networking during Job Search}

Networking behaviors are a potentially important factor driving gender differences in social networks and contributing to the gender gap in career achievement, yet we know little about how and why gender shapes networking behavior. To fill this gap, we study the networking behavior of female and male job-seekers in a strategic research setting. In Study 1, we use server logs to directly observe job-seeking MBAs students' outreach to alumni and show that female students reach out to at least as many men and to significantly more women than their male classmates. In Study 2, 46 interviews reveal that in addition to all the same networking that men do, female jobseekers also networked, primarily with women, to assess two aspects of fit that men were less concerned about: gender dynamics and support for parenting. Taken together, our results suggest that both genders engage in schmoozing to get a job, but women also engage in scouting - a heretofore undocumented form of gender-homophilous networking aimed at finding employers and career options that give women a fair chance at professional success. We discuss the implications of our findings for our understanding of gender differences in networks and career attainment. 
Voluminous research has documented the gender gap in career attainment. It is wellknown and oft-lamented that women are underrepresented in management jobs, concentrate in roles and occupations that offer lower pay and fewer opportunities for professional advancement, encounter more barriers to entry into high-level managerial positions, and earn less, on average, for the work that they do than men (Jacobsen 1994; Petersen \& Morgan 1995; Halaby 2003; Eagly \& Carli 2007; Fernandez-Mateo 2009; Ely, Ibarra \& Kolb 2011). Researchers from a broad range of intellectual backgrounds have weighed in on the myriad reasons for this gap. One influential line of research shows that gender differences in social networks - the patterns of interpersonal relationships that characterize people's social and professional lives - contribute significantly to this gender gap in attainment (e.g. Brass 1985; Burt 1992; Ibarra 1992; Fernandez \& Sosa 2005; Lutter 2015).

One potential driver of these gender differences in social networks is networking behavior, or the purposeful creation of new social ties for achievement of professional goals, that is a ubiquitous feature of modern life (Ingram \& Morris 2007; Vissa 2012; Kuwabara, Hildebrand \& Zou 2016). Prior research on women's and men's social networks suggests a variety of reasons why women might network differently than men: either because women are excluded from male power structures (e.g. Kanter 1977; Mehra, Kilduff \& Brass 1998) or because they seek different resources than men (e.g. Ibarra 1992; Yang, Chawla \& Uzzi 2019). Yet, surprisingly, existing studies of job-related networking, or networking that people engage in to get their work done, find little evidence of gender differences in networking intensity or in networking styles (e.g. Aldrich, Reese, \& Dubini 1989; Forret \& Dougherty 2004; Bensaou, Galunic \& Jonczyk-Sedes 2016). 
To extend our understanding of gender differences in networking behavior, we depart from prior work focused on job-related networking, and focus instead on job-search networking, or networking undertaken to facilitate new employment. Prior research suggests that through contacts, job-seekers can identify job openings, explore potential career options, assess their "fit" with different organizations, refine their self-presentation during interviews, or even find advocates in the organization (Granovetter 1974; Castilla, Lan \& Rissing 2013; Barbulescu 2015; Greenberg \& Fernandez 2016). Not surprisingly, for professional and managerial workers, job-search networking is widely seen as a key to success in job search (Sharone 2013, 2017). One important advantage of focusing on job-search networking for our study is that all professional and managerial workers engage in it, unlike job-related networking that might be more common in some job functions (Bensaou, Galunic \& Jonczyk-Sedes 2016).

To examine gender differences in job-search networking, we employ a mixed-methods sequential explanatory design (Ivankova, Creswell \& Stick 2006) and leverage a strategic research setting: an elite MBA program, where job-seeking students network with alumni ${ }^{1}$, and where we were able to both obtain unique digital trace data quantifying networking outreach and also access individuals for deeper qualitative insights. In Study 1, we use server logs of students' networking outreach to alumni to show quantitatively that, given access to the same pool of potential contacts, women engage in significantly more networking than men do. Empirically, this surplus in women's networking behavior includes reaching out to at least as many men and to significantly more women than their male peers. In Study 2, we interviewed 46 job-seeking women and men to examine the content of women's networking surplus identified in Study 1.

\footnotetext{
${ }^{1}$ For parsimony and gender equity, we use the singular abbreviation "alum" and the mixed-gender plural "alumni" or "alums" throughout, rather than the more formal, but gender-specific, Latin words "alumnus," "alumna," and "alumnæ".
} 
We find that women and men network with alumni for many of the same reasons, including to obtain instrumental help, to explore career opportunities, and for insights regarding "fit" with potential employers. In addition, female job-seekers also networked, primarily with women, to access two aspects of fit that men were less concerned about: gender dynamics and support for parenting.

Together our results suggest that while both women and men engage in schmoozing ${ }^{2}$, an intuitively well-understood form of networking which is geared towards identifying and securing a new position; women also engage in scouting, a heretofore unexplored form of networking that seeks information - primarily from other women - about how the work environment in a firm or an industry treats women, specifically. Importantly, we find that this incremental form of networking done by women does not lead to better (or to worse) job search outcomes. Instead, our evidence suggests that it is a kind of "discrimination insurance" women take to avoid professional contexts unhospitable to women or to their needs and concerns (Shih 2006). Such insurance can be costly, redirecting time and effort from one's primary tasks (Sharone 2013, 2017) to tasks that may consume cognitive and emotional energy because they are fraught, onerous or uncomfortable (Casciaro, Gino \& Kouchaki 2014).

This paper contributes to the literatures on social networks and gender in labor markets and will, we hope, reinvigorate research at their intersection. To start, our study partitions jobsearch networking into two distinct activities, schmoozing and scouting. Further, we elaborate scouting as women's gender-homophilous networking behavior that, over time, may give rise to the gendered network structures documented in prior research (Ibarra 1992, 1997; Kleinbaum,

\footnotetext{
2 The word "schmooze" derives from the Yiddish word שמועo (shmues) which, in turn, derives from the Hebrew word שִׁמועוע (shmuot), meaning "bits of news" or "rumors". In English, it is a colloquialism that means to socialize in a way that builds relationships, sometimes with a connotation of instrumentality. In other words, it perfectly captures the conventional wisdom on how people network in their job searches.
} 
Stuart \& Tushman 2013). Importantly, scouting is motivated by the unique benefits that samegender relationships offer to women in a world of potential discrimination (Ibarra 1992, 1997; Yang, Chawla \& Uzzi 2019) and does not derive from men rebuffing women's networking attempts (c.f. Kanter 1977; Mehra, Kilduff \& Brass 1998). More broadly, our study extends theories of deliberate tie formation through networking (Casciaro, Gino \& Kouchaki 2014; Kuwabara, Hildebrand \& Zou 2018), the relationship between network access and mobilization (Kwon \& Adler 2014; Obukhova \& Lan 2013), and structure and agency in network research more generally (Tasselli \& Kilduff 2020).

\section{EMPIRICAL SETTING}

For this study, we focused on the job search networking of students in an elite MBA program, a research setting that allowed us the opportunity to collect unique digital data on students' outreach to the university's alums, as well as to conduct in-depth follow-up interviews. Networking with alums is critical in MBA job search, as students use contacts to identify possible career opportunities, learn about prospective employers, prepare for interviews, and find advocates and mentors within hiring organizations (Barbulescu 2015; Greenberg \& Fernandez 2016). While networking with alums is certainly not the only type of networking MBA students engage in, access to an alumni network is an important selling point for many MBA programs, including the one we studied.

Most notably, our data contain digital traces of students' use of the alumni database. This database contains information about all living alums of the school, including name, class year, gender, citizenship, prior education, contact information, and information about their current and some prior employment, including firm name, job title, industry, and job function. Some records, particularly those for recent alums, include a photo. The database is searchable by any of the 
fields above. Most information is quite current, with the median record updated just 18 months prior to the start of the academic year that we studied. Importantly, our data contains information on all network outreach by students, regardless of whether it was reciprocated. This means we do not restrict our sample to successful networking attempts (as, for example, would a study focusing on the addition of LinkedIn contacts), which would potentially bias results by excluding those interactions where the networking attempt was ignored or rejected.

Our research setting has a number of other advantages that are important to note. Most importantly, by giving women and men access to similar networking opportunities our research site minimizes the effect of one potential confounder on gender differences in networking. An important challenge for studying the gender differences in networking is to empirically distinguish differences in networking strategies from a gender difference in access to networking opportunities. Researchers have long emphasized that women might face barriers in access to networking opportunities, including knowing fewer people to start with (Ely, Ibarra \& Kolb 2011; Bapna \& Funk 2018). In our context, all students, upon enrolling in business school, are granted access to alumni via the school's alumni database. And the strong affiliation that many alumni feel toward the school makes the particularly receptive to inquiries from students. This allows us to observe gender differences in networking behavior, conditional on access to the same pool of potential contacts, more directly than any prior study of which we are aware, and to do so in a field setting.

Furthermore, focusing on MBA students at a single university enables us to examine networking behavior among comparably qualified women and men, ruling out a number of potential confounders such as variation in the quality of education, prior experience, and other types of human capital. Familial responsibilities, another potential factor that might limit 
women's opportunities to network in other settings (Forret \& Dougherty 2004), are also relatively scarce in our setting, as most MBA students are young professionals (the median age is 30) and over $94 \%$ are without children.

As in prior work on MBA job search (e.g., Sterling 2014), we analyze internship searches by first-year students, rather than searches for full-time employment by second-year students, for greater comprehensiveness and temporal synchrony. In the two-year MBA program where the data for this study were collected, virtually all first-year students search for a summer internship, which they consider to be a critical step in the search for full-time employment after graduation. Because employers make offers to some students following the internship, many students do not search for jobs during the second year; this fact would create a sample selection issue for studying the search for full-time jobs by second-year students. Focusing on the internship search thus allows us to study networking behavior without concern about self-selection into job search, conditional on membership in the population (though we acknowledge that not all job searches involve equal amounts of networking). Further, the timing of the full-time job search varies more widely across students, compared to the search for first-year internships, which is relatively compressed.

\section{STUDY 1: METHODS}

We examine how a complete cohort of 287 first-year MBA students used the alumni database in their searches for summer internships. This research required the collection of three distinct data sets. ${ }^{3}$ First, and most notably, we collected server logs of students' use of the alumni database. Students using the database can search alums' profiles using keywords, industry tags,

\footnotetext{
${ }^{3}$ All of these data sets are linked through the use of anonymous identifiers, which enable us to link the data about individual students and alums with the database activity logs while protecting the privacy of both students and alums.
} 
firm or person names, and a variety of other means. Logs of which alums appeared in their search results were recorded over an eleven-month period, beginning in the summer prior to the matriculation of first-year students, when they first gained access to the database, and through the end of their first year, when virtually all students had started their internships. In particular, we logged each time a student viewed an alum's profile page and each click on the "mailto:" link (an "emailclick"), an action that initiates a new email from the student to the alum. For each such emailclick, a precise timestamp and the ID numbers of the searching student and the target alum were logged. Thus, rather than relying on self-reports of past networking, we track actual emailclick behaviors, coming as close as possible to observing networking (albeit of one particular type) directly. Anecdotal accounts suggest that an emailclick from the alumni database is by far the primary means by which students initiate contact with unknown alums.

Second, we collected individual-level data about all living alumni of the school. The alumni data included each alum's gender, employer, industry, and job title and description. The job description data were selected by alums themselves from a typology of thirteen possible titles, ranging from "Analyst/Associate/Consultant" and "Student/Intern/Resident” to "Partner/Principal/Managing Director/VP” and "CEO/President/Chairman.” Overall, the alum population is $78.2 \%$ male and $21.8 \%$ female. If we restrict the alumni population to those who graduated in the prior twenty, ten, or five years, the proportion of female alums rises to $30.8 \%$, $31.5 \%$, and $33.3 \%$, respectively, in large part because the school we studied was all-male in its early history. Female alums are not confined to particular jobs or industries: if we restrict the alumni population to those in job functions or industries in which many students seek employment, the gender composition remains substantively similar. 
Third, we assembled individual-level data on the students from three sources. The registrar provided data on each student's gender, citizenship, native language, and ethnicity; campus residence status (i.e., whether they lived on campus or off); class section; relative GMAT score ${ }^{4}$; and marital status. We also conducted our own survey in October, collecting psychometric data and data on students' networking strategies. And finally, the career development office provided data on students' attendance at company briefings as well as data from two student surveys. The pre-matriculation survey conducted in August inquired about each student's intentions regarding the firms, industries, and job functions in which they planned to search for internships. We exclude from our sample ten students who indicated that they did not intend to search for internships because they were pursuing dual degrees (primarily MD/MBA students) or would be returning to a previous employer ${ }^{5}$. The internship outcome survey conducted in May collected information on students' self-reported satisfaction with the internship received; note that this survey was conducted after the internship offer was signed, but before the internship began. We also added some items to the May survey to evaluate the validity of our emailclick measures.

\section{Variables}

Our primary dependent variable, emailclick, is a count variable equal to the total number of clicks on alums' "mailto:" links made by each student. We argue - and below present some evidence to support this assertion - that this is an excellent proxy for the number of emails a student initiated to alums with whom they were not previously acquainted. To examine the gender distribution of each student's networking targets, we split the count of alums contacted

\footnotetext{
${ }^{4}$ For reasons of confidentiality, GMAT data were provided to us not as raw scores, but as standardized variables, calculated relative to this cohort of students, with a mean of zero and a standard deviation of one by construction. ${ }^{5}$ Note, however, that some dual-degree and sponsored students indicated that they nevertheless did intend to search for internships; these were retained in our primary sample.
} 
into subsets of female (emailclick_f) and male (emailclick_m) alums; by construction, emailclick $=$ emailclick $f+$ emailclick $\_m$.

Our main explanatory variable is Female, coded as one for female students and as zero for male students. ${ }^{6}$ We also create a number of control variables that are likely to affect networking and on which women and men might plausibly differ. We expect that the personality trait Extraversion is associated with intensity of networking behaviors (Forret \& Dougherty 2001; Shipilov et al. 2014) and may be associated with gender (Lynn \& Martin 1997 show a correlation in the general population, but Feiler \& Kleinbaum 2015 find no correlation in an MBA student sample), so we measured it using the extraversion scale from the Big Five Inventory (John \& Srivastava 1999). We expected that students who are less occupationally focused might search more broadly, and that occupational focus might co-vary with gender (Barbulescu \& Bidwell 2013), so using information from the August career survey, we created a variable Search Breadth to measure the number of job functions in which a student expressed an interest in working.

We controlled for demographic characteristics. We created three dummy variables (Asian, White and Other) to control for students' race and another dummy variable to indicate whether the student is a Native English Speaker. We created a dummy variable Sponsored for those students whose tuition was paid by their past employer, in return for a promise that they would resume their employment after business school. Because these students are likely to return to their employer upon graduation, their job search motivations - and, consequently, their

\footnotetext{
${ }^{6}$ At the time of the study, the university only collected binary information about gender. To avoid confounding biological sex with gender identity, we included in our survey instrument the Bem (1974) Sex Role Inventory (BSRI), which measures masculine and, separately, feminine gender roles. We find weak evidence that people who identify with male gender roles independent of their biological sex may reach out to female alumni less and that women who identify with female gender roles may reach out to female alumni more. But these results are muddled by the insignificant main effect of gender and only appear when gender role is interacted with biological sex. Further research is needed to better understand these results, which appear in Appendix Table A1-4.
} 
networking patterns - might differ from those students who are not sponsored (though in many cases, sponsored students still search for a summer internship with a different employer). Lastly, we include two measures of human capital. A continuous variable GMAT $(s t d)$ measures the distance in standard deviations between a student's score on the Graduate Management Admissions Test and the mean GMAT score in the sample. And Log Work Experience is the natural logarithm of the number of years of professional experience prior to beginning business school. We calculated years of work experience as the number of years between the end of the student's undergraduate degree and the start of business school, less the number of years spent in other educational programs, as indicated in students' reporting to the registrar.

\section{STUDY 1: RESULTS}

We begin by presenting some descriptive statistics. Means, standard deviations and intercorrelations for all variables are presented in Table 1; a histogram depicting the distribution of emailclick by student's gender appears in Figure 1. To support the validity of emailclick as a behavioral indicator of networking activity, we note that students searching for jobs had more emailclicks than those not searching for jobs $(\mathrm{p}<0.04)$ and those who reported in our October survey that they viewed the alum database as a valuable job search resource had more emailclicks than those who did not $(\mathrm{p}<0.001)$. To further assess the validity and reliability of emailclicks as a measure of networking activity, we included in the May survey a page in which we showed respondents the names and employers of some alums whom server logs indicated they had previously emailclicked and other alums whom server logs indicated they did not emailclick. We then asked them about their interactions with these alums. We found that when we observed an emailclick to a specific alum, students reported having interacted with that alum 
$78 \%$ of the time; conversely, when we observed no emailclick, students reported having interacted with the alum only $16 \%$ of the time $e^{7}$. Given imperfect recall in survey response and other channels of possible interaction between students and alums, we found these results to be strong evidence supporting the validity of emailclicks.

\section{<Insert Table 1 about here> \\ <Insert Figure 1 about here>}

The distribution of emailclicks across students is skewed ${ }^{8}$ : about one-third (35.3\%) of students did not emailclick any alums. Overall, we find little evidence of a gender difference in whether or not students used the database. Selection models (available upon request) indicate that gender is not a significant predictor of positive use of the alum database $(p=0.796)$, so given equal opportunity to network with alumni, women take advantage of that opportunity at a rate equal to that of men. Also, no other key covariate predicts which students choose not to emailclick any alums. Indeed, the only significant predictors of positive (versus zero) emailclicks are a stated interest in jobs in financial services $(\mathrm{p}=0.023)$ or human resources $(\mathrm{p}=0.012)$. Anecdotally, students report a belief that financial services is a highly competitive industry in which networking beyond the formal recruiting process is de rigeur; conversely, relatively few HR positions are available through on-campus recruiting, so networking with alums may be an alternative avenue to finding such a job.

Our descriptive results would seem to confirm the intuition that the use of the database is closely linked to internship search activity, especially to early stages of learning about job opportunities, identifying potential employers, and networking with employees at firms of

\footnotetext{
${ }^{7}$ For greater comparability, and recognizing that the majority of alums have no interactions with students at all, the non-emailclicked alums were selected from among those with the highest rates of interaction with students other than the focal student.

${ }^{8}$ But as our robustness section below indicates, our results are not driven by outliers.
} 
interest. Emailclicks occur disproportionally before internship offers are received (84.2\% for men; $85.3 \%$ for women; $\mathrm{p}=0.321$ ); for comparison, the median internship offer was received on February $10^{9}$. We also find that both female and male students use the database to network broadly: 95\% of emailclicks are targeted at alums who do not work at the firm where the student ended up interning. This result also does not differ significantly by gender, whether we look at all networking activity throughout the year $(\mathrm{p}=0.363)$ or only networking activity occurring before the student received an internship offer $(\mathrm{p}=0.471)$.

Before moving on to multivariate analyses, we descriptively examined networking behaviors, focusing on differences between male and female students, in Table 2. The most striking descriptive result is that women, on average, reach out to fully $63 \%$ more alums (6.5 vs. $3.99 ; \mathrm{p}=0.031)$ than men do. Further, this difference appears to be explained by the facts that women, compared with men, contact nearly three times as many female alums ( 2.42 vs. $0.88 ; \mathrm{p}<$ 0.001 ) and at least as many male alums (4.08 vs. $3.10 ; \mathrm{p}=0.14)$. These differences hold up in non-parametric Mann-Whitney tests, which show that women contact marginally more alums overall $(\mathrm{p}=0.05)$; significantly more women $(\mathrm{p}<0.01)$ but no fewer men $(\mathrm{p}=0.46)$. We depict these differences in Figure 2, a scatter plot of emailclick_m against emailclick $f$ by student's gender.

$<$ Insert Figure 2 about here>

Comparing these descriptive statistics to the alumni population as a whole, we note that for male students, the aggregate gender distribution of alums contacted closely parallels the gender distribution of the alumni population: collectively, $77.8 \%$ of male students' emailclicks were to male alums and $22.1 \%$ were to female alums, a distribution that is indistinguishable from

\footnotetext{
${ }^{9}$ The median male student received an offer on February $11^{\text {th }}$; the median female student received an offer on February $9^{\text {th }}$.
} 
the gender distribution of the alum population $(\mathrm{p}>0.4)$. Female students, however, directed $37.2 \%$ of their emailclicks to female alums, a rate significantly higher $(\mathrm{p}<0.0001)$ than women's representation in the alums population. If we restrict our focus to more recent cohorts of alumni, women consistently over-sample female alums in their networking behavior relative to the availability of women in the "risk set" of available alums; although men seem to sample at random with respect to gender overall, they do over-sample men in their outreach to more recent alums. These patterns are illustrated in Figure A1-1 in Appendix 1.

<Insert Table 2 about here>

We present the results of multivariate Poisson quasi-maximum likelihood regressions in Table 3, beginning with control variables ${ }^{10}$. Poisson count models are in the linear exponential family, so the conditional mean of the data is assumed to be correctly specified, but no additional distributional assumption is required to generate consistent coefficient estimates (Silva \& Tenreyro, 2006). We find little difference in networking behavior by students of different ethnicities: relative to their white peers, the Asian coefficient is statistically insignificant in all models. Students of Other Ethnicities (other than white or Asian) may use the alum database less. Non-native English speakers may also use the alum database less, but again, the effects are inconsistent. Students engaging in a broad job search (that is, those who indicated interest in more job functions on our August survey) tend to use the alum database more and students whose tuition was sponsored by a previous employer - to whom they are committed to returning - use it less. People with extraverted personalities use the alum database more, but the effect is only estimated precisely enough for statistical significance in interactions with female alums.

<Insert Table 3 about here>

\footnotetext{
${ }^{10}$ Because U.S. Citizenship is highly correlated (0.71) with Native English Speaker, we drop the citizenship variable to avoid problems of multicollinearity. Results are substantively unchanged if we retain citizenship instead.
} 
We test for the presence of gender differences in the number of contacts a student reached out to in Model 1, where the dependent variable is the total count of emailclicks. Controlling for other observable demographic characteristics, we find that female students, on average, click on the mailto links of $43 \%$ more alums than their male classmates $\left(e^{0.360}=1.43 ; \mathrm{p}\right.$ $<0.05)$. To examine the role of contacts' gender in differences in students' networking, we look to Models 2 and 3, whose dependent variables are emailclick $f$, the count of emailclicks directed to female alums, and emailclick_m, the count of emailclicks directed to male alums, respectively. In Model 2, female students mobilize ties to female alums at 2.27 times the rate of their male classmates $\left(=e^{0.819} ; \mathrm{p}<0.001\right)$. Importantly, we find that female students do not reach out to female alums at the expense of ties to male alums: Model 3 indicates that women may also reach out to more male alums, though the effect size is modest and imprecisely estimated $\left(e^{0.174}=1.19\right.$; $\mathrm{p}=0.350)$.

Robustness. These results are robust to numerous alternative explanations, which we briefly summarize here. First, our results are not driven by industry effects; we replicated our core empirical analyses with industry controls and still found that women reach out to at least as many men and significantly more women than men do. Specifically, we replicated the analysis in Table 3 using industry controls based on students' stated internship search interests (Appendix 1, Table A1-1) and, alternatively, based on the industry in which the student accepted an internship (Appendix 1, Table A1-2). In these models with industry controls, we find that the Emailclick coefficient on female is positive, though no longer significant. This could suggest that women's greater propensity to network that we find is at least in part driven by women seeking jobs in industries where networking is more prevalent, such as consulting or human resources. Nevertheless, consistent with "scouting," in all the models with industry controls we still find 
that compared to men, women reach out to more female alums (i.e., $\beta_{\text {Emailclick_f }}>0 ; p<0.05$ ) and to no fewer male alums (i.e., $\beta_{\text {Emailclick_m }}$ cannot be discerned from 0$){ }^{11}$

Second, the differences do not reflect women pursuing a broader job search. We have re-estimated our models with controls for the number of industries students expressed an interest in. Across all preliminary models, these variables were not significant and their inclusion did not substantively affect our results. ${ }^{12}$ Finally, we dropped this control variable altogether to see whether another covariate (especially gender) would pick up this variation; these results were also substantively unchanged.

Third, women might use the online alumni database more heavily than men because they prefer electronic communication to communicating in person. Theoretically, if women anticipate gender bias, communicating electronically might reduce that bias by making gender less salient than it would be in face-to-face interaction. To test for such channel substitution, we collected data from the career development staff on students' in-person attendance at on-campus company presentations and include the number of company presentations attended as a covariate in our emailclick models. We find that attendance at company briefings has a weak, positive association with networking via the alum database - that is, more in-person networking is associated with more, rather than less, electronic networking - and does not diminish the networking surplus of scouting. In all, the evidence available to us suggests that women's networking surplus is not attributable to substitution from other communication channels.

\footnotetext{
${ }^{11}$ Relatedly, we worried that these effects might be stronger in some industries than others, but unreported analyses reveal that the effects are substantially the same for job-seekers who ended up with internships in stereotypically male industries (financial services or tech) versus those who ended up in more gender-neutral industries (consulting, consumer goods or healthcare) or job functions (general management or marketing).

${ }^{12}$ Although our primary use for the company briefing data described in the next paragraph is to test for channel substitution, we note that it may also give a more behavioral indicator of search breadth. Substituting the number of company briefings attended in place of the Search Breadth variable defined by job functions yielded results that were substantively unchanged.
} 
Fourth, we worried that if women receive unhelpful responses to their networking outreach generally (Abraham 2019) or more helpful responses from women (Greenberg \& Mollick 2017), this might spur additional networking, specifically targeting female alums. So we surveyed students about the responsiveness and helpfulness of alums to their network outreach. In the survey conducted in May, students were presented with a list of alums and asked about their interactions with each alum and what type of help (if any) the alum provided. Types of help included "providing general career advice," informing about a job opening" and "acting as a referral". Using dyad-level, random-effects, linear probability models we found no gender difference: both female and male alums appear to be equally likely to respond to female and male students and to provide them with the same amount of help (Appendix 1, Table A1-3).

Fifth, due to the skewness of the emailclick variable, we worried that the effect might be driven by a few uninhibited outliers engaging in extensive networking with alums. As a robustness check, we replicated Table 3 using a subsample of students that excludes those who contacted at least twenty alums. In these analyses, the gender difference in emailclick, and emailclick $f$ diminishes slightly in magnitude, but is otherwise substantially similar, suggesting that these are not outlier effects.

Finally, we were concerned that the gender difference we observe could be the compensatory result of women's weak pre-MBA networks. Although we lack data to assess this mechanism directly ${ }^{13}$, we attempt to address this possibility indirectly by examining function- and industry-switchers: those students who accepted internships in a job function and/or an industry different from their pre-MBA work experience. We focus on this subset of job

\footnotetext{
${ }^{13}$ The most direct way to assess this mechanism would be to measure the outside networks of MBA students - for example, as represented on LinkedIn, a business and employment-oriented online social network - and compare men's and women's networks. However, LinkedIn's privacy policy precludes us from obtaining the data necessary to assess network size, let alone structure or quality.
} 
seekers because regardless of gender, their prior work experience is likely to have left them with pre-existing networks that are of relatively little value in finding their subsequent employment. If the mechanism underlying the gender gap in networking behavior stems from women's desire to compensate for their weaker pre-existing networks, then we should expect that in this subsample, where both men and women lack relevant professional networks, the gender difference in networking should be attenuated or eliminated entirely. Across all of these subsamples of switchers, the gender surplus in networking persists and, indeed, is even larger than in the full sample: compared to their male peers, female switchers network with more than double the number of alums. We interpret this as evidence inconsistent with a mechanism of compensation for weak pre-existing network. Finally, we note that women and men are equally likely to switch job functions $(\mathrm{p}>0.12)$, industries $(\mathrm{p}>.26)$, or both $(\mathrm{p}>0.32)$, so the increase in the gender gap in networking activity is not the spurious result of a gender difference in propensity to change jobs.

Thus, to summarize the core result of Study 1, when a group of MBA students is presented with the same pool of potential contacts for networking, women reach out to male alums at a rate that is comparable with that of their male counterparts; in addition, they consistently reach out to significantly more female alums. Furthermore, we tested and found little evidence for various explanations of these results. Our quantitative results suggest that these patterns are not explained by differences in characteristics of industries in which women and men seek jobs; by the breadth of their job-searches; their preference for communication medium; by the responses they receive from alumni or the strength of their pre-existing networks. What, then, explains the incremental networking behavior engaged in by women? 


\section{STUDY 2: METHODS}

To investigate more deeply why women manifest this networking surplus, we conducted two sets of follow-up interviews to elucidate two specific questions raised by the quantitative results. To answer the first question - What benefits do female job-seekers get from networking that men do not? - a team of MBA research assistants (5 men and 5 women) conducted 41 exploratory interviews in May 2017 with 20 female and 21 male MBA students. The interviews included questions about what students hoped to get out of networking, how they accessed organizational fit, and asked students to describe one or two specific experiences with alumni networking (see interview guide in Appendix 2A-1). The average interview length was 20 minutes. The interviews were recorded and professionally transcribed.

In order to allow gender differences to emerge unprompted, we wanted to keep these interviews conversational and informal. As MBA students often compare notes on the interview process, we recruited MBA students to conduct these interviews in order to put informants at ease and reduce social desirability bias. We worried that a researcher who was familiar with the research question might inadvertently signal to subjects what kinds of things we were interested in or looking for. Using interviewers who are blind to the research question avoided this potential source of bias. MBA research assistants were completing an intensive research-based, seminarformat course that required them to read original research papers and discuss them. Thus, they had some exposure to research methods, both quantitative and qualitative. Second, we gave them a brief primer in conducting qualitative interviews, emphasizing the importance of an openended interview process.

To keep the interview process as natural as possible, we also did not place restrictions on whom students could interview, aside from encouraging them to interview a roughly equal 
number of women and men. Our interview subjects are indistinguishable from the broader cohort of students in terms of their gender $(t=0.401)$ and marital status $(t=-0.473)$; they are slightly more likely to be U.S. citizens $(81 \%$ vs. $65 \% ; \mathrm{t}=-2.30 ; \mathrm{p}<0.05)$ and are younger by a statistically significant, but practically meaningless amount $(27.4$ vs. 28.4 years old; $t=3.63 ; \mathrm{p}<$ 0.001). While we do not claim that the resulting sample is representative of the student population in the program we studied, it did result in a balanced sample reflecting the diversity of the students in the program, including 28 white students and 12 minority students, 36 single students and 4 married ones.

We used a four-step, inductive theme-development approach (Gioia, Corley \& Hamilton 2012) to analyze these qualitative data. In Step 1, we identified first-order concepts using students' own terms. In Step 2, we grouped first-order concepts into a smaller number of secondorder emergent themes. After iterating between student's terms and emerging themes (Locke 2001), we arrived at a preliminary list of themes. In Step 3, using this list, we identified themes with important differences between female and male MBA students. In Step 4, to further refine our second-order themes, we repeated Steps 2-4 for those themes that exhibited substantial gender differences. For example, while our preliminary list of themes included "work-life balance," closer reading of the first-order concepts grouped under this theme, revealed that women were more concerned than men about one specific subset of work-life balance issues: those relating to parenting. Iterative cycles of transcript-reading and discussion revealed two themes - gender dynamics and support for parenting - that only appeared in interviews with women, reflecting women's concerns that were not shared by men.

After we identified these themes, and to answer a second question raised by the results above - Why do women scout with other women? - one of the co-authors conducted five 
additional explanatory interviews with female MBA students in September 2018. As the interviews aimed to reveal and explain motivations behind behavior observed in exploratory interviews, we asked open-ended questions about what they gained from networking with other women, why they thought it was important to network with other women and their interpretation of our results (see interview guide in Appendix 2A-2).

\section{STUDY 2: RESULTS}

Schmoozing vs Scouting

As the data structure in Table 4 shows, our exploratory interviews revealed many similarities in how female and male students approached job search networking, but also two striking differences. To start, we found that both female and male students used networking to schmooze - that is, to explore career opportunities, including learning about industries, roles, and career strategies, to identify job leads, to obtain interview help, referrals and even advocacy. Furthermore, both female and male students sought information about the internal workings of firms in order to assess their potential fit. Collectively, we term this behavior schmoozing and it is the facet of job-search networking that is most widely perceived and understood.

However, two themes came up in exploratory interviews with female job-seekers about their job-search networking that did not come up in conversations with male job-seekers. These themes concerned gender dynamics and employers' support for parenting. Collectively, we term the incremental networking that women do to explore these issues scouting. Out of 20 women interviewed, 9 women brought up at least one of the themes comprising scouting, whereas none of the men did. Importantly, these issues came up unprompted, suggesting that they are relatively top-of-mind for a significant number of female job-seekers. Furthermore, women across industries brought up these issues, signifying that they are not unique to those who enter 
stereotypically masculine industries, such as finance and technology, or those who enter more gender neutral industries, such as healthcare and consulting.

In our exploratory interviews, seven women (35\%) brought up workplace gender dynamics as a topic that they explored in their networking. For example, when asked about how she assessed fit, Avery (F10), mentioned that considering how open the company was to women was an important factor in her decision-making:

I wanted to know how receptive the company was to women... I also asked questions in the call about how is the experience of women at these organizations, on how people socialize there, work life balance etc.

Another student, Lucy (F18), related a long conversation with a female alum who described a time when the employer gave sports vests as company gifts, without realizing that such vests were more suitable as business casual attire for men than for women. Lucy noted that that she enjoyed the conversation because it candidly acknowledged the types of issues women are likely to encounter in a consulting career:

I like when I meet women who recognize that there is a problem with women in consulting. Who aren't like, 'Oh, well I got here, so it's fine.'

We also found that throughout our interviews, female MBAs reported asking more questions and more specific questions about work-life balance (e.g. flexible hours, need for travel). More tellingly, support for parenting was one aspect of work-life balance that did not arise in interviews with men at all, but was mentioned by five women (25\%). This is particularly striking, given that only one woman in our exploratory interview sample was a parent. Kate (F4), for example, described asking about maternity leave policies as well as other issues affecting employees with children:

I asked a lot about maternity leave policies. And also asked about the flexibility with work-life balance post having kids. If they [the alums] have kids or if they didn't have 
kids, how they perceived their coworkers with children, since that would be a factor fairly shortly after I start.

Another student, Jen (F-13), also asked about support for women with children:

I said, "I don't mean to bring this up, I'm not married, I'm not having kids any time soon, but I do want to build a career at a bank. So, I want to understand what is the support like for women having children?"

This finding is consistent with research that suggests that women are more likely to ask for parenting accommodations openly, while men seek them through informal means, partly because corporate policies are more likely to target women than men (Reid 2015).

Shared minority status and gender homophily in scouting

To further explore why women network with more women, we conducted five additional interviews where we specifically asked students for their interpretation of our results. In these interviews, women noted that they found it more comfortable to approach other women and that they expected women to be more helpful. For example, Bella (F21) noted that in choosing networking targets she: "just gravitated towards younger females." Amal (F25) described that she assumed that "a woman will see the email and respond, and maybe it is intimidating to email someone you do not know... [With a woman] it is easier to form a connection, which is kind of what you want from these calls." Similarly, Alexandria (F23) noted:

I assumed women will be more receptive to my pitch. And sometimes ... if I am reaching out to a gentleman, for better or for worse, I feel more under the microscope... This might come off bad, but as a woman, I will always be objectified in a certain way.

We also find that MBA women approached female alums because they assumed that other women confront similar obstacles to professional advancement that men do not. For 
example, Nina (F25) told us that she sought information about gender dynamics from women because men did not directly experience them:

I think if there are issues with how women are treated differently from men, they are going to be real with you about it. It's harder for a man to do if they're not directly experiencing it.

Similarly, Pooja (F24) found that when she was asking questions about maternity leave and support for employees with children, women knew better "where [she] was coming from":

Another woman would ... know where I'm coming from when I'm asking these questions. They probably thought through the same issues. ... I feel like you're more likely to find a woman who's done that thinking than you are to find a man.

In addition, we find that female job-seekers hoped that reaching out and connecting to these female alums was a first step in forming a supportive relationship for the future because of their shared minority status. For example, Lucy (F18) related that when a classmate mentioned a sister who was working the same industry and was also an alum, Lucy reached out because she hoped this classmate's sister was going to become her friend:

She's probably going to be my friend which was the goal at this point. If she said, "My brother does the same thing, "I wouldn't reach out to her, but in particular because she was a woman, I felt a special connection.

In contrast, women were reluctant to discuss these issues with men. For example, in investigating prospective employers, Bella (F21) wanted to learn about women in leadership positions, gender pay differences, and misogyny in the workplace. Yet she was reluctant to brings these issues up with male alums noting "I don't know that I ever would have felt comfortable asking a man about those things."

In summary, the qualitative evidence in Study 2 indicates that the women's networking surplus documented in the quantitative evidence of Study 1 is attributable - at least in part - to women's homophilous networking to better understand issues around gender dynamics in the 
workplace and the organization's support for parenting. These results may reflect that many of these women are entering jobs in firms and industries that remain disproportionally male, where concerns about gender dynamics are particularly salient. It is also not surprising that for some of these women - who are in their late 20 s and early 30 s - parenting becomes an important concern. What is striking about our results is how starkly absent these concerns were for the men we interviewed and the extent to which the women we interviewed assumed that male alums might lack the knowledge and/or willingness to discuss these issues with women.

\section{DISCUSSION}

Networking behaviors are a potentially important factor driving gender differences in social networks and contributing to the gender gap in career achievement, yet we know little about how and why gender shapes networking behavior. To answer these questions, we focused on students' job search networking in an elite MBA program, a setting that has the important advantage of giving women and men access to an identical pool of contacts. The results of Study 1 suggest that female job-seekers, while reaching out to the same number of male alums as men did, also reached out to significantly more female alums. Qualitative interviews in Study 2 suggested an explanation for this difference: that in addition to networking for information and access, just as men do, women engage in incremental networking, mostly with other women, to access two aspects of fit that men were less concerned about: gender dynamics and support for parenting. Taken together, these results suggest that, in addition to the schmoozing that men also do, women engage in scouting, a heretofore unexamined gender-homophilous form of networking aimed at finding employers and career options where they will have the best chance of professional success. Importantly, women do not contact more women at the expense of 
contacting men: women engage in scouting in addition to doing all the same schmoozing that men engage in.

Our data suggest little association between networking activity and individual-level outcomes: once we control for the industry of the internship, we do not find gender differences in internship salary, satisfaction, or timing of receiving an offer (unreported results). There are a number of ways to interpret these results. It is possible that our outcome measures were not nuanced enough to pick up genuine differences. It is possible that our highly-structured setting solves some empirical challenges (e.g., giving men and women an equal opportunity set of potential contacts), but creates others (e.g., internship programs may have uniform salaries for all candidates). However, it is also likely that the lack of the association is due to an endogeneity in networking behavior. Consider that people who network the most might be people who had the hardest time finding a job (e.g. Loury 2006). If this is the case, the association between emailclicks and outcomes might, in fact, be negative. Only future research with a different research design can lead to an accurate causal interpretation.

While our analysis focused on gender, we suspect that other negatively-stereotyped minorities also engage in "scouting". Data limitations precluded us from a rigorous quantitative analysis of whether racialized minorities engaged in scouting, but our interviews yielded some evidence of scouting among women of color and international students. For example, Bola (F19), a Black woman, related that she particularly valued discussions with - and deliberately sought out - people "like herself" to better understand what her experience at a particular firm might be like:

When I was talking to alums, the ones that I felt that I could connect with the most-so it'd be women or minorities - I asked them questions about fit because I knew that they would be able to give me a perspective that would be of value to me....There would be no point 
asking somebody that I felt was very different from me, and ... because if they enjoy the fit, I may not... I would level up and be, 'Just tell me exactly how it is over here.'

This sentiment was echoed by Alexandria, a Latinx woman (F23), who reported that when networking, she "was excited if there was a woman of color or person of color." We leave it to future research to more systematically examine the intersectional question of whether networking behavior varies by race or other social status and whether scouting plays a similar role for other racialized minorities and international students as it does for women.

\section{Scouting as "Discrimination Insurance”}

As such, scouting constitutes a kind of "discrimination insurance" that is costly to women, but which, they hope, will prevent larger challenges later. One way in which scouting as "discrimination insurance" manifests itself can be found in discussions prompted by the \#MeToo movement, which emerged on social media in the fall of 2017 and which brought to light the existence of "whisper networks" (New York Times 2017). Whisper networks are reputed to discuss workplace sexual misconduct, harassment and assault, but also more mundane areas in which women might encounter gender-based obstacles, like how to handle office politics, salary negotiations, promotion processes and work-life balance issues. Journalistic reporting in the wake of the \#MeToo movement has revealed many anecdotes of women in media, technology and finance who relied on such networks, but, as their name suggests, they have eluded systematic research. Our results suggest that these "whisper networks" are not an isolated phenomenon related to sexual misconduct, harassment and assault, but rather one - perhaps the most extreme - manifestation of women's attempts to "scout out good jobs" by seeking and sharing information with other women.

While scouting has these benefits, it is costly to women who engage in it. The most obvious cost in our context is the time and effort required in networking, an activity that many 
consider to be unpleasant (Casciaro, Gino \& Kouchaki 2014; Kuwabara, Hildebrand \& Zou 2016). Because time is the scarcest resource of all busy professionals, the incremental networking that women do must come at the expense of other activities. Given time constraints, reaching out to more people can be carried out at the expense of deepening existing networking ties. This might be particularly harmful for women, for whom research suggest it is important to have an inner circle of strong ties (Burt 1998; Yang, Chawla \& Uzzi 2019). Such “functionally differentiated networking" also likely leads to the evolution of functionally differentiated networks, in which women seek and receive emotional support and help from women, while they turn to men for instrumental help (Ibarra 1992).

An interesting implication of the "discrimination insurance" metaphor is the possibility that the insurance is simply too costly for some women ${ }^{14}$. That is, some women who did not explore issues related to gender dynamics and support for parenting with their network contacts may have avoided doing so, despite holding such concerns, perhaps because they are too busy to invest in scouting or perhaps out of fear of the signal that doing so might send (e.g., getting labeled as "difficult" or as "mommy track;" Reid 2015). The possibility that scouting sends a potentially negative signal was brought up by one of our respondents, Jen (F-13). Interestingly, she argued that by asking potentially stigmatizing questions about a firm's gender representation at the VP level and its support for parenting, she believed that she was signaling to potential employers her interest in a long-term career because "if a woman isn't asking you those questions, you can't believe that she actually wants to work at this firm long term." Unfortunately, our research design did not enable us to assess how often this occurred - that is, we did not ask informants who did not raise such concerns why they did not. We leave it for

\footnotetext{
${ }^{14} \mathrm{We}$ are grateful to an anonymous reviewer for this intriguing insight.
} 
future research to explore the long-term career consequences of scouting (or not scouting) as well as how the signals sent by scouting are received by others.

\section{IMPLICATIONS AND CONCLUSION}

Our study contributes to the growing literature on networking in professional contexts. Our finding - that in job search, women engage in incremental scouting with other women, in addition to doing the same schmoozing that men do - is at odds with the results of the other research into job-related networking behaviors, which have found little evidence of gender differences in networking intensity or in networking styles (Aldrich, Reese, \& Dubini 1989; Forret \& Dougherty 2004; Casciaro, Gino \& Kouchaki 2014; Bensaou, Galunic \& JonczykSedes 2016). This discrepancy has two important implications. First, it provides additional support to our interpretation that the women's networking surplus we observed is linked to concerns about professional opportunities for women, rather than women's inherent propensity for sociability or homophily. Second, it underscores the importance of future research on networking to explore systematically what resources women and men seek through networking to elucidate in which contexts gender differences in networking are likely to emerge.

This study also makes two significant contributions to the literatures on networks and gender. To start, our study suggests that, at least in the present context, gender homophily in women's job-search networking is not a product of men rebuffing women's networking attempts (c.f. Mehra, Kilduff \& Brass 1998), but rather of the unique benefits same-gender relationships offer to women. Prior research on gender and networks (e.g., Ibarra 1992, 1997; see also Kleinbaum, Stuart \& Tushman 2013) has often found it difficult to determine whether gender homophily in intra-organizational networks results from men's exclusion of women, or women's 
pursuit of same-same relationships. We find, consistent with other studies that describe the benefits of same-gender relationships for women (Ibarra 1992, 1997; Yang, Chawla \& Uzzi 2019), that during networking, women actively seek out other women because they seek unique gender-relevant resources from these relationships.

Our study also shines new light on the gendered processes of tie formation and mobilization. Despite the evidence that the benefits individuals derive from social networks do not explain how they create and mobilize social ties (Ryall \& Sorenson 2007; Buskens \& van de Rijt 2008; Obukhova \& Lan 2013; Kwon \& Adler 2014), most research in the social network field has focused on network structure, largely neglecting the agentic processes of tie formation (Casciaro, Gino \& Lobo 2014: Kuwabara, Hildebrand \& Zou 2016; Kleinbaum, Jordan \& Audia 2015; Kneeland 2019). The neglect of attention to these processes is problematic for future development of the social network field, as it tries to understand not only career consequences of individual differences in networks, but also processes that give rise to these differences in the first place (Kilduff, Tsai \& Hanke 2006; Ahuja, Soda \& Zaheer 2012; Kleinbaum 2012, 2018). By isolating the role of gender in giving rise to individual differences in networking outreach, our study makes an important step toward revealing processes that lead to individual difference in networks. And by revealing differences in how individuals network our study brings us one step closer to understanding the role of agency in social networks.

Our study suggests important new directions for the research on gender in the labor market. Prior research suggests that women pre-emptively steer out of jobs where they expect to encounter hiring discrimination, hostile work cultures, and other gender-based obstacles (Fernandez-Mateo \& Fernandez 2016; see also Goldsmith et al. 2004; Barbulescu \& Bidwell 2013), yet we are only beginning to understand how they make such decisions. Some studies 
show that to form some of these judgements about an employer's culture women use publicly available signals, such as the gender of the CEO (Campero \& Kacperczyk 2019) or the language used in the recruitment presentation (Wynn \& Correll 2018). Our study shows that networking can be another important mechanism through which women assess fit with potential employers and evaluate career options. Together with the revelations about the importance of women's networks in male-dominated industries brought forth by the \#MeToo movement, our study suggests the need for future research to explore how networking can inform women's labor supply decisions.

Like all research, this study is not without limitations. One limit on the generalizability of our results stems from features of the MBA setting itself. Our setting offered a unique opportunity to study network outreach using a combination of digital data and qualitative interviews. This setting also offered an equal opportunity set of potential contacts (i.e., the alumni database) to all students of both genders, equalizing the opportunity structure for networking. And to a first approximation, all job seekers in this setting are comparable in their human capital. However, these benefits come at a significant cost. It goes without saying that this population is selected from the broader population in a decidedly non-random way, so we cannot know the extent of generalizability of our results. Furthermore, MBA programs go to significant lengths to remove structural barriers to women networking, for example by encouraging networking to take place in gender-neutral spaces. And while work by Shih (2006) on Silicon Valley white female engineers suggests the possibility that scouting may not be unique to MBA women, we leave it for future research to investigate how gender shapes networking in other parts of the labor market. 
In spite of these limitations, our study has significant practical implications for organizational and societal efforts to promote gender equity. Our work highlights that, until society can remove the barriers that women (and, perhaps, negatively-stereotyped minorities) face in the workplace, resources like alumni databases offer the potential benefits of providing them with access to networking opportunities. While many employers have realized the importance of using diverse recruiting teams to provide job candidates with opportunities to interact with someone like them (Lockwood 2006) in order to learn informally about a prospective employer (Rivera 2015: 46, 70), our study highlights that contacts can be sourced by candidates themselves using alumni databases. This is important as increasingly, it is not only universities, but also firms who think about their former affiliates as alumni (e.g., The Economist 2014; Forbes 2016) and as internet technologies make such databases of potential contacts more accessible than ever before. Our results suggest that these institutional efforts to create networking opportunities are a valuable response to gender-based barriers in the workplace, in that they give women greater, if costly, opportunity to "scout for good jobs." 


\section{REFERENCES}

Abraham, M. 2019. Gender-role incongruity and audience-based gender bias: An examination of networking among entrepreneurs. Administrative Science Quarterly.

Ahuja, G., Soda, G., \& Zaheer, A. 2012. The Genesis and Dynamics of Organizational Networks. Organization Science, 23(2): 434-448.

Aldrich, H., Reese, R.P., \& Dubini, P. 1989. Women on the verge of a breakthrough: Networking among entrepreneurs in the United States and Italy. Entrepreneurship and Regional Development, 1(4): 339-356.

Bapna, S., \& R. Funk. 2018. An Experimental Assessment of Interventions for Improving Women's Professional Networking: Results from IT. Social Science Research Network. Available at https://ssrn.com/abstract=3157260.

Barbulescu, R. 2015. The strength of many kinds of ties: Unpacking the role of social contacts across stages of the job search process. Organization Science, 26(4): 1040-1058.

Barbulescu, \& R., Bidwell, M. 2013. Do women choose different jobs from men? Mechanisms of application segregation in the market for managerial workers. Organization Science, 24(3): 737-756.

Bem, S. L. 1974. The Measurement of Psychological Androgyny. Journal of Consulting and Clinical Psychology, 42(2): 155.

Bensaou, B.M., Galunic, C., \& Jonczyk-Sédès, C. 2014. Players and purists: Networking strategies and agency of service professionals. Organization Science, 25(1): 29-56.

Brass, D.J. 1985. Men's and women's networks: A study of interaction patterns and influence in an organization. Organization Science, 28(2): 327-343.

Burt, R.S. 1992. Structural Holes. Cambridge, MA: Harvard University Press.

Burt, R.S. 1998. The gender of social capital. Rationality and Society, 10(1): 5-46.

Buskens, V., \& van Rijt, A. 2008. Dynamics of networks if everyone strives for structural holes. American Journal of Sociology, 114(2): 371-407.

Campero, S., \& A. Kacperczyk 2019. Homophily versus Status-seeking in the Search for Startup Jobs. Paper presented at Center for Industrial Relations \& Human Resources, University of Toronto.

Casciaro, T., Gino, F., \& Kouchaki, M. 2014. The contaminating effects of building instrumental ties: How networking can make us feel dirty. Administrative Science Quarterly, 59(4): 705735.

Castilla, E.J., Lan, \& G.J., Rissing, B.A. 2013. Social networks and employment: Mechanisms (part 1). Sociology Compass, 7(12): 999-1012.

The Economist. 2014 “Corporate Alumni: Gone But Not Forgotten.” (March 1, 2014). Last accessed June 21, 2017 at: http://www.economist.com/news/business/21597935-more-firms-areseeking-stay-touch-former-staff-gone-not-forgotten.

Eagly, A. H. \&Carli, L.L. 2007. Through the Labyrinth: The Truth about How Women Become

Leaders. Harvard Business School Press: Cambridge, MA.

Ely, R. J., Ibarra, H., \& Kolb, D. M. 2011. Taking gender into account: Theory and design for women's leadership development programs. Academy of Management Learning \& Education, 10(3): 474-493.

Feiler, D.C., \& Kleinbaum, A.M. 2015. Popularity, similarity, and the network extraversion bias. Psychological Science, 26(5) : 593-603.

Fernandez, R. M., \& Sosa, M. L. 2005. Gendering the job: Networks and recruitment at a call center.

The American Journal of Sociology, 111: 859-904.

Fernandez-Mateo, I. 2009. Cumulative gender disadvantage in contract employment. American

Journal of Sociology, 114(4): 871-923. 
Fernandez-Mateo, I., \& Fernandez, R.M. 2016. Bending the pipeline? Executive search and gender inequality in hiring for top management jobs. Management Science, 62(12): 3636-3655.

Forbes 2016. "Why McKinsey \& Company's Alumni Network Is Crucial To Its Success." Last accessed June 21, 2017 at https://www.forbes.com/sites/davidburkus/2016/07/05/whymckinsey-companys-alumni-network-is-crucial-to-its-success/.

Forret, M.L., \& Dougherty, T.W. 2004. Networking behaviors and career outcomes: Differences for men and women? Journal of Organizational Behavior, 25: 419-437.

Gioia, D. A., Corley, K. G., \& Hamilton, A. 2012. Seeking qualitative rigor in inductive research. Organizational Research Methods, 16(1): 15-31.

Granovetter, M. 1974 (1995). Getting a job: A study of contacts and careers (2nd ed.). Chicago: University of Chicago Press.

Greenberg, J., \& Fernandez, R.M. 2016. The strength of weak ties in MBA job search: A withinperson test. Sociological Science.

Greenberg, J., \& Mollick, E. 2017. Activist choice homophily and the crowdfunding of female founders. Administrative Science Quarterly, 62(2): 341-374.

Halaby, C. N. 2003. Where job values come from: Family and schooling background, cognitive ability, and gender. American Sociological Review, 68: 251-278.

Ibarra, H. 1992. Homophily and differential returns: Sex-differences in network structure and access in an advertising firm. Administrative Science Quarterly, 37(3): 422-447.

Ibarra, H. 1997. Paving an alternative route: Gender differences in managerial networks. Social Psychology Quarterly, 60(1): 91-102.

Ingram, P., \& Morris, M. W. 2007. Do people mix at mixers? Structure, homophily, and the "life of the party". Administrative Science Quarterly, 52(4): 558-585.

Ivankova, N.V., Creswell, J.W., \& Stick, S.L. 2006. Using mixed-methods sequential explanatory design: From theory to practice. Field Methods, 18(1): 3-20.

Jacobsen, J. 1994. The Economics of Gender. Willey-Blackwell.

John, O.P., \& Srivastava, S. 1999. The big five trait taxonomy: History, measurement, and theoretical perspectives. Pp. 102-138. Handbook of Personality: Theory and Research, Pervin, L.A., \& John O.P., eds. Guilford Press, New York.

Kilduff, M., Tsai, W., \& Hanke, R. 2006. A paradigm too far? A dynamic stability reconsideration of the social network research program. Academy of Management Review, 31(4): 10311048.

Kleinbaum, A. M. 2012. Organizational misfits and the origins of brokerage in intrafirm networks. Administrative Science Quarterly, 57(3): 407-452.

Kleinbaum, A. M. 2018. Reorganization and tie decay choices. Management Science, 64(5): 22192237.

Kleinbaum, A. M., Jordan, A. H., \& Audia, P. 2015. An altercentric perspective on the origins of brokerage in social networks: how perceived empathy moderates the self-monitoring effect. Organization Science, 26(4): 1226 - 1242.

Kleinbaum, A.M., Stuart, T.E., \& Tushman, M.L. 2013. Discretion within constraint: Homophily and structure in a formal organization. Organization Science, 24(5): 1316-1336.

Kneeland, M. K. 2019. Agency and the Dynamics of Network Churn, NYU-Stern Working Paper. New York.

Kuwabara, K., Hildebrand, C., \& Zou, X. 2016. Lay theories of networking: How laypeople's beliefs about networks affect their attitudes and engagement toward instrumental networking.

Academy of Management Review, 43(1): 50-64.

Kwon, S.-W., \& Adler, P.S. 2014. Social capital: maturation of a field of research. Academy $\boldsymbol{o f}$ Management Review, 39(4): 412-422.

Locke, K. D. 2001. Grounded theory in management research. London: Sage. 
Lockwood, P. 2006. "Someone like me can be successful": Do college students need same-gender role models? Psychology of Women Quarterly, 30(1): 36-46.

Loury Datcher, L. 2006. Some contacts are more equal than others: Informal networks, job tenure, and wages. Journal of Labor Economics, 24(2): 299-318.

Lutter, M. 2015. Do women suffer from network closure? The moderating effect of social capital on gender inequality in a project-based labor market, 1929 to 2010. American Sociology Review, 80(2): 329-358.

Lynn, R., \& Martin, T. 1997. Gender differences in extraversion, neuroticism, and psychoticism in 37 nations. Journal of Social Psychology, 137(3); 369-373.

Mehra, A., Kilduff, M., \& Brass, D. J. 1998. At the margins: A distinctiveness approach to the social identity and social networks of underrepresented groups. Academy of Management Journal, 41(4); 441-462.

New York Times 2017. “Women's Whisper Network Raises Its Voice.” Last accessed June 14, 2019 at https://www.nytimes.com/2017/11/04/business/sexual-harassment-whisper-network.html.

Obukhova, E., \& Lan, G. 2013. Do job seekers benefit from contacts? A direct test with contemporaneous searches. Management Science, 59(10); 2204-2216.

Petersen, T., \& Morgan, L.A. 1995. Separate and unequal: Occupation establishment sex segregation and the gender wage gap. American Journal of Sociology. 101(2): 329-365.

Reid, E. 2015. Embracing, passing, revealing, and the ideal worker image: How people navigate expected and experienced professional identities. Organization Science, 26(4): 997-1017.

Rivera, L.A. 2015. Pedigree: How elite students get elite jobs. Princeton University Press, Princeton, NJ.

Ryall, M.D., \& Sorenson, O. 2007. Brokers and competitive advantage. Management Science, 53(4): 566-583.

Sharone, O. 2013. Flawed System/Flawed Self: Job Searching and Unemployment Experiences. Chicago: University of Chicago Press.

Sharone, O. 2017. LinkedIn or LinkedOut? How social networking sites are reshaping the labor market. In A. L. Kalleberg, \& S. Vallas (Eds.), Emerging Conceptions of Work, Management and the Labor Market: 1-31: Emerald Publishing.

Shih, J. 2006. Circumventing discrimination: Gender and ethnic strategies in Silicon Valley. Gender and Society, 20(2):177-206.

Shipilov, A., Labianca, G., Kalnysh, V., \& Kalnysh, Y. 2014 Network-building behavioral tendencies, range, and promotion speed. Social Networks, 39: 71-83.

Silva, J.M.C.S, Tenreyro S. 2006. The log of gravity. Review of Economics and Statistics, 88(4): 641-658.

Sterling, A.D. 2014. Friendships and search behavior in labor markets. Management Science, 60(9): 2341-2354.

Tasselli, S. \& Kilduff, M. 2020. Error! Hyperlink reference not valid. The Academy of Management Annals.

Vissa, B. 2012. Agency in action: Entrepreneurs' networking style and initiation of economic exchange. Organization Science, 23(2): 492-510.

Yang, Y., Chawla, N. V., \& Uzzi, B. 2019. A network's gender composition and communication pattern predict women's leadership success. Proceedings of the National Academy of Sciences, 116(6): 2033-2038. 


\section{BIOGRAPHICAL SKETCH}

Elena Obukhova (elena.obukhova@mcgill.ca) is an Assistant Professor in the Strategy and Organization area at McGill University. Trained as an economic sociologist, she studies the effects of social structures on economic exchange, with a particular focus on how social networks affect job search strategies and outcomes.

Adam M. Kleinbaum (adam.m.kleinbaum@tuck.dartmouth.edu) is an Associate Professor in the Strategy and Management area at the Tuck School of Business at Dartmouth College. His research employs diverse methods to examine the formation and evolution of social networks in organizations. 
Figure 1. Histogram of the total number of alums contacted per student, separated out by the gender of the student. The distribution may be skewed slightly to the right for female students, compared to male students $(\mathrm{p}=0.084)$.

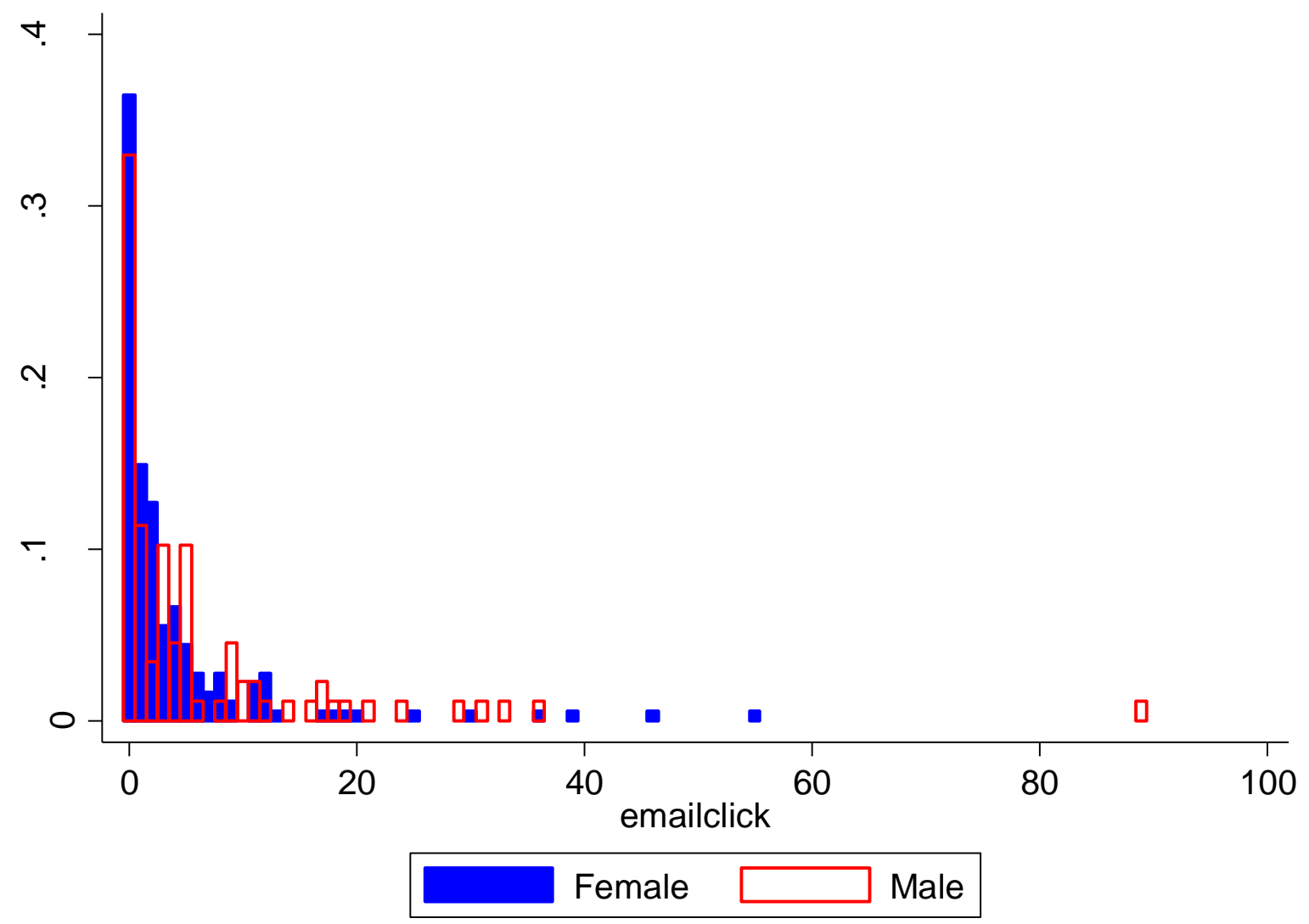


Figure 2. Scatter plot of emailclick_m against emailclick $f$ by gender, with random perturbations to better visualize discrete data. Male students (red dots) are clustered below the line, contacting a disproportionate number of male alums, whereas female students (blue Xs) are clustered above the line, contacting a disproportionate number of female alums.

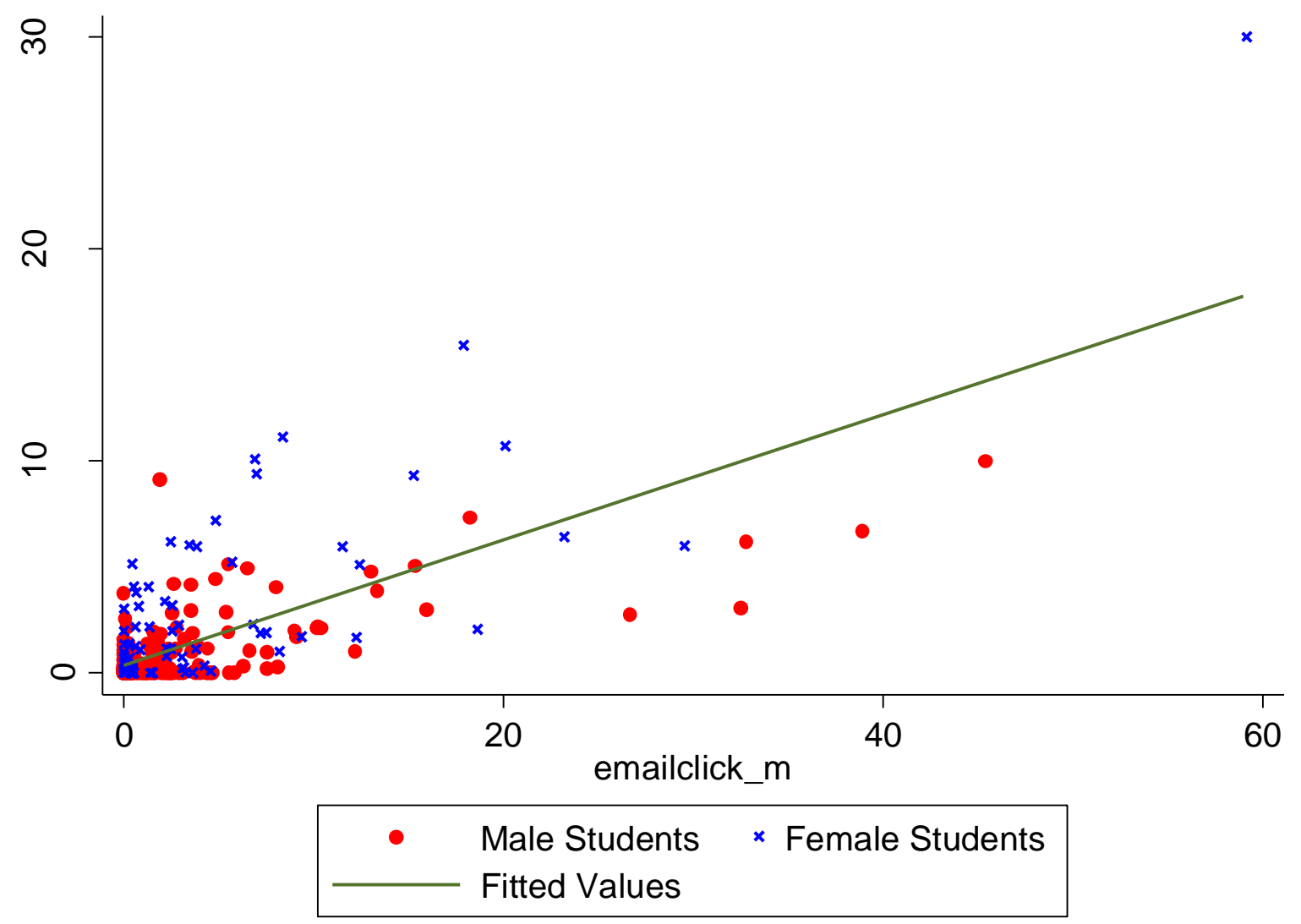


Table 1. Descriptive statistics.

\begin{tabular}{|c|c|c|c|c|c|c|c|c|c|c|c|c|c|c|}
\hline & & Mean & SD & (1) & (2) & (3) & (4) & (5) & (6) & (7) & (8) & (9) & (10) & (11) \\
\hline (1) & Female & 0.33 & 0.47 & 1 & & & & & & & & & & \\
\hline$(2)$ & emailclick & 4.81 & 9.40 & 0.10 & 1 & & & & & & & & & \\
\hline (3) & emailclick_f & 1.39 & 2.90 & 0.25 & 0.79 & 1 & & & & & & & & \\
\hline (4) & emailclick_m & 3.42 & 7.09 & 0.04 & 0.97 & 0.63 & 1 & & & & & & & \\
\hline (5) & GMAT (std) & -0.01 & 1.00 & -0.21 & 0.03 & -0.06 & 0.06 & 1 & & & & & & \\
\hline (6) & Sponsored & 0.02 & 0.15 & -0.05 & -0.08 & -0.06 & -0.08 & -0.02 & 1 & & & & & \\
\hline (7) & Native English Speaker & 0.61 & 0.49 & 0.04 & -0.09 & 0.00 & -0.11 & 0.06 & -0.03 & 1 & & & & \\
\hline (8) & Extraversion & 3.39 & 0.82 & -0.04 & 0.07 & 0.13 & 0.05 & 0.00 & 0.06 & 0.16 & 1 & & & \\
\hline (9) & Search Breadth & 0.29 & 0.46 & 0.01 & 0.17 & 0.16 & 0.16 & 0.00 & -0.04 & 0.03 & -0.02 & 1 & & \\
\hline (10) & On Campus Resident & 0.52 & 0.50 & 0.17 & 0.08 & 0.06 & 0.08 & -0.02 & 0.00 & -0.06 & 0.07 & -0.03 & 1 & \\
\hline (11) & U.S. Citizen & 0.64 & 0.48 & 0.05 & -0.09 & 0.00 & -0.11 & -0.08 & 0.01 & 0.71 & 0.17 & -0.01 & -0.05 & 1 \\
\hline (12) & Log Prior Experience & 1.74 & 0.33 & -0.08 & -0.01 & -0.01 & -0.01 & -0.02 & -0.03 & 0.01 & -0.11 & -0.01 & -0.03 & -0.02 \\
\hline
\end{tabular}


Table 2. Descriptive analysis of networking behaviors with alums by male and female job-seekers, showing mean values (standard deviations in parentheses) and the p-values of simple, one-tailed t-tests of whether female job seekers contacted more alums than male job-seekers, on average.

\begin{tabular}{|l|c|c|c|c|}
\hline & $\begin{array}{c}\text { Average Male } \\
\text { Job-Seeker }\end{array}$ & $\begin{array}{c}\text { Average Female } \\
\text { Job-Seeker }\end{array}$ & $\begin{array}{c}\text { Magnitude of } \\
\text { difference }\end{array}$ & $\begin{array}{c}\text { p-value of } \\
\text { difference }\end{array}$ \\
\hline emailclick & $3.99(7.73)$ & $6.50(12.00)$ & $+63 \%$ & $0.0310^{*}$ \\
emailclick_f & $\mathbf{0 . 8 8 ( 1 . 6 9 )}$ & $2.42(4.28)$ & $+175 \%$ & $\mathbf{0 . 0 0 0 7 * * *}$ \\
emailclick_m $m$ & $\mathbf{3 . 1 0}(6.46)$ & $4.08(8.24)$ & (n.s.) & $\mathbf{0 . 1 4 2 7}$ \\
\hline
\end{tabular}


Table 3. Regressions of networking activity with all alums (Model 1) and with female and male alums (Models 2-3) for the full sample of student job seekers.

\begin{tabular}{|l|c|cc|}
\hline & $\mathbf{( 1 )}$ & $\mathbf{( 2 )}$ & $\mathbf{( 3 )}$ \\
Female & emailclick & emailclick_f & emailclick_m \\
\hline \multirow{4}{*}{ Asian } & $0.359^{*}$ & $0.822^{* * *}$ & 0.171 \\
Other Ethnicity & $(0.174)$ & $(0.195)$ & $(0.187)$ \\
& 0.0674 & 0.222 & -0.00809 \\
GMAT (std) & $(0.295)$ & $(0.309)$ & $(0.339)$ \\
& $-0.575^{+}$ & -0.331 & $-0.655^{+}$ \\
Sponsored & $(0.325)$ & $(0.339)$ & $(0.360)$ \\
& 0.0132 & -0.0731 & 0.0603 \\
Native English Speaker & $(0.0818)$ & $(0.0705)$ & $(0.106)$ \\
& $-2.025^{* *}$ & $-1.132^{*}$ & $-2.822^{* *}$ \\
Extraversion & $(0.667)$ & $(0.494)$ & $(0.985)$ \\
& $-0.552^{+}$ & -0.171 & $-0.706^{*}$ \\
Search Breadth & $(0.297)$ & $(0.291)$ & $(0.352)$ \\
& 0.231 & $0.360^{*}$ & 0.185 \\
Log Work Experience & $(0.180)$ & $(0.168)$ & $(0.197)$ \\
& $0.613^{*}$ & $0.549^{*}$ & $0.633^{*}$ \\
& $(0.257)$ & $(0.223)$ & $(0.291)$ \\
Constant & -0.0162 & 0.0780 & -0.0566 \\
& $(0.239)$ & $(0.338)$ & $(0.233)$ \\
\hline Observations & 0.791 & -1.598 & 0.873 \\
& $(0.872)$ & $(1.009)$ & $(0.919)$ \\
\hline Standard & 256 & 256 & 256 \\
\hline
\end{tabular}

Standard errors in parentheses

${ }^{+} p<.10,{ }^{*} p<.05,{ }^{* *} p<.01,{ }^{* * *} p<.001$ 
Table 4. Data structure derived from first-phase exploratory interviews. First order themes with examples of first order concepts in quotes.

\begin{tabular}{|c|c|c|}
\hline OBJECTIVE & WOMEN & MEN \\
\hline \multicolumn{3}{|l|}{ Schmoozing } \\
\hline Instrumental Help & $\begin{array}{l}>\text { "figure out if X was hiring" } \\
\text { "what the company is } \\
\text { looking for and how to } \\
\text { prepare myself for the } \\
\text { interview" } \\
>\text { "get my resume picked out } \\
\text { of the pile" }\end{array}$ & $\begin{array}{l}\text { "opportunities at the firm" } \\
\text { "to get vocabulary to talk } \\
\text { intelligibly for when I } \\
\text { actually have interviews" } \\
>\text { "make a good impression } \\
\text { that would lead to a hire" }\end{array}$ \\
\hline Career Opportunities & $\begin{array}{l}\text { "zeroing in on something in } \\
\text { the industry that was a } \\
\text { trend" } \\
\text { "hoping to understand is } \\
\text { this for me, is this industry } \\
\text { for me, is this company for } \\
\text { me" } \\
\text { "what skills companies } \\
\text { looking for to prepare at X } \\
\text { business school" }\end{array}$ & $\begin{array}{l}>\text { "tell me your story, what's } \\
\text { exciting in industry X" } \\
>\text { "learn about X position, } \\
\text { how X worked" } \\
>\text { "understand what was } \\
\text { helpful to come into the job } \\
\text { with" }\end{array}$ \\
\hline Organizational Culture & $\begin{array}{l}>\text { "trying to understand what } \\
\text { is unique about each } \\
\text { company" } \\
\text { "could I hang out with } \\
\text { people in the office?" } \\
>\text { "sustainability of personal } \\
\text { life and work" }\end{array}$ & $\begin{array}{l}>\text { "looking for fit - a job I } \\
\text { would do for a long time" } \\
>\text { "the language, the style, } \\
\text { sense of goals and } \\
\text { ambitions" } \\
>\text { "work life balance" }\end{array}$ \\
\hline \multicolumn{3}{|l|}{ Scouting } \\
\hline Gender Dynamics & $\begin{array}{l}>\text { "how receptive was the } \\
\text { company to women" } \\
>\text { "ask about women at VP } \\
\text { level" }\end{array}$ & \\
\hline Support for Parenting & $\begin{array}{l}>\text { "how colleagues perceived } \\
\text { co-workers with kids" } \\
>\text { "maternity leave policies" }\end{array}$ & \\
\hline
\end{tabular}




\section{APPENDIX 1: SUPPLEMENTARY ANALYSES FOR STUDY 1}

Figure A1-1: Students' networking choices (by gender) relative to the risk set of available alumni.

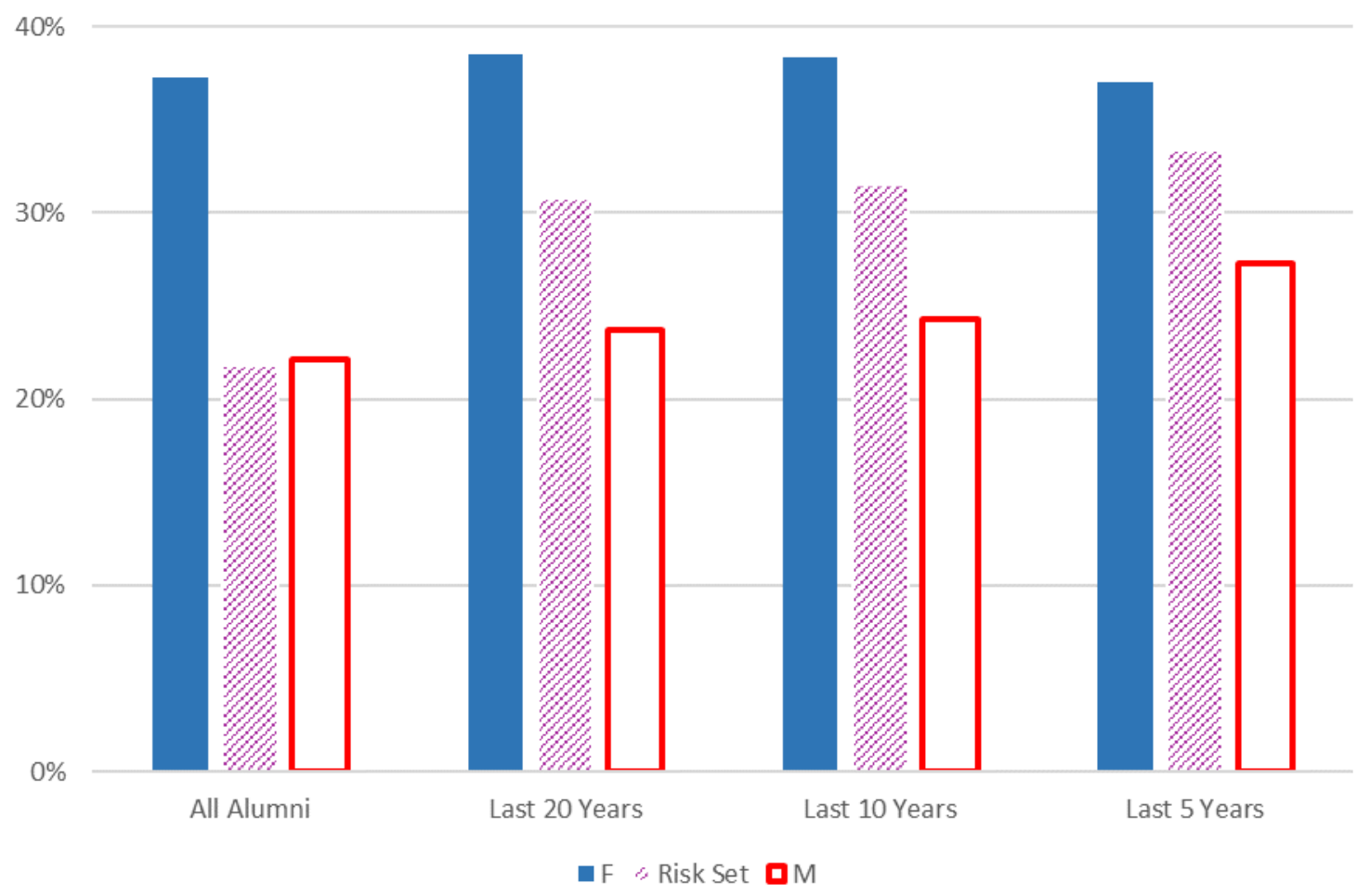


Table A1-1. Regressions of networking activity with all alums (Model 1) and with female and male alums (Models 2-3) for the full sample of student job seekers (as in Table 3), controlling for each student's ex ante career interests.

\begin{tabular}{|c|c|c|c|}
\hline$D V:$ & $\begin{array}{c}(1) \\
\text { emailclick }\end{array}$ & $\begin{array}{c}\text { (2) } \\
\text { emailclick_f }\end{array}$ & $\begin{array}{c}\text { (3) } \\
\text { emailclick_m }\end{array}$ \\
\hline \multirow[t]{2}{*}{ Female } & 0.222 & $0.629^{* *}$ & 0.0465 \\
\hline & $(0.207)$ & $(0.200)$ & $(0.228)$ \\
\hline \multirow[t]{2}{*}{ Asian } & -0.0379 & 0.238 & -0.165 \\
\hline & $(0.318)$ & $(0.292)$ & $(0.364)$ \\
\hline \multirow[t]{2}{*}{ Other } & $-0.501^{+}$ & -0.247 & $-0.583^{+}$ \\
\hline & $(0.289)$ & $(0.276)$ & $(0.343)$ \\
\hline \multirow[t]{2}{*}{ GMAT (std) } & -0.0134 & -0.106 & 0.0380 \\
\hline & $(0.106)$ & $(0.0776)$ & $(0.134)$ \\
\hline \multirow[t]{2}{*}{ Sponsored } & $-2.007^{* *}$ & $-1.123^{*}$ & $-2.794^{* *}$ \\
\hline & $(0.697)$ & $(0.495)$ & (1.007) \\
\hline \multirow[t]{2}{*}{ Native English Speaker } & -0.394 & -0.0412 & -0.546 \\
\hline & $(0.351)$ & $(0.291)$ & $(0.418)$ \\
\hline \multirow[t]{2}{*}{ Extraversion } & 0.224 & $0.327^{* *}$ & 0.180 \\
\hline & $(0.140)$ & $(0.124)$ & $(0.158)$ \\
\hline \multirow[t]{2}{*}{ Search Breadth } & $0.566^{*}$ & $0.445^{*}$ & $0.625^{*}$ \\
\hline & $(0.232)$ & $(0.214)$ & $(0.270)$ \\
\hline \multirow[t]{2}{*}{ Log Work Experience } & -0.0608 & 0.0876 & -0.115 \\
\hline & $(0.270)$ & $(0.358)$ & $(0.270)$ \\
\hline \multirow[t]{2}{*}{ Interest in Consulting } & $0.546^{*}$ & 0.0140 & $0.737^{* *}$ \\
\hline & $(0.221)$ & $(0.318)$ & $(0.238)$ \\
\hline \multirow[t]{2}{*}{ Interest in Finance } & -0.204 & $-0.396^{+}$ & -0.143 \\
\hline & $(0.181)$ & $(0.241)$ & $(0.201)$ \\
\hline \multirow[t]{2}{*}{ Interest in General Mgmt } & -0.351 & 0.0321 & $-0.493^{+}$ \\
\hline & $(0.288)$ & $(0.474)$ & $(0.297)$ \\
\hline \multirow[t]{2}{*}{ Interest in Human Res. } & $0.883^{* *}$ & $0.602^{*}$ & $0.989^{* * *}$ \\
\hline & $(0.325)$ & $(0.295)$ & $(0.358)$ \\
\hline \multirow[t]{2}{*}{ Interest in Info Tech } & 0.382 & 0.255 & 0.424 \\
\hline & $(0.247)$ & $(0.261)$ & $(0.269)$ \\
\hline \multirow[t]{2}{*}{ Interest in Marketing } & 0.108 & $0.528^{*}$ & -0.0458 \\
\hline & $(0.209)$ & $(0.246)$ & $(0.225)$ \\
\hline Constant & $\begin{array}{c}0.620 \\
(0.717)\end{array}$ & $\begin{array}{l}-1.700^{*} \\
(0.789)\end{array}$ & $\begin{array}{c}0.680 \\
(0.812)\end{array}$ \\
\hline Observations & 256 & 256 & 256 \\
\hline
\end{tabular}

Standard errors in parentheses

${ }^{+} p<.10,{ }^{*} p<.05,{ }^{* *} p<.01,{ }^{* * *} p<.001$ 
Table A1-2. Regressions of networking activity with all alums (Model 1) and female and male alums (Models 2-3) for the full sample of student job seekers (as in Table 3), controlling for the industry of each student's eventual internship.

\begin{tabular}{|c|c|c|c|}
\hline$D V:$ & $\begin{array}{c}\text { (1) } \\
\text { emailclick }\end{array}$ & $\begin{array}{c}(2) \\
\text { emailclick_f }\end{array}$ & $\begin{array}{c}\text { (3) } \\
\text { emailclick_m }\end{array}$ \\
\hline Female & $\begin{array}{c}0.308 \\
(0.233)\end{array}$ & $\begin{array}{l}0.666^{*} \\
(0.261)\end{array}$ & $\begin{array}{c}0.156 \\
(0.250)\end{array}$ \\
\hline Asian & $\begin{array}{c}0.195 \\
(0.280)\end{array}$ & $\begin{array}{c}0.345 \\
(0.276)\end{array}$ & $\begin{array}{c}0.122 \\
(0.331)\end{array}$ \\
\hline Other & $\begin{array}{l}-0.452 \\
(0.355)\end{array}$ & $\begin{array}{l}-0.229 \\
(0.346)\end{array}$ & $\begin{array}{l}-0.528 \\
(0.409)\end{array}$ \\
\hline GMAT (std) & $\begin{array}{l}-0.107 \\
(0.110)\end{array}$ & $\begin{array}{l}-0.225^{*} \\
(0.0922)\end{array}$ & $\begin{array}{c}-0.0460 \\
(0.133)\end{array}$ \\
\hline Sponsored & $\begin{array}{l}-1.976^{* *} \\
(0.706)\end{array}$ & $\begin{array}{l}-1.293^{*} \\
(0.572)\end{array}$ & $\begin{array}{l}-2.652^{* *} \\
(1.004)\end{array}$ \\
\hline $\begin{array}{l}\text { Native English } \\
\text { Speaker }\end{array}$ & $\begin{array}{l}-0.504 \\
(0.334)\end{array}$ & $\begin{array}{l}-0.109 \\
(0.285)\end{array}$ & $\begin{array}{l}-0.666 \\
(0.413)\end{array}$ \\
\hline Extraversion & $\begin{array}{c}0.348 \\
(0.213)\end{array}$ & $\begin{array}{l}0.462^{* *} \\
(0.168)\end{array}$ & $\begin{array}{c}0.305 \\
(0.235)\end{array}$ \\
\hline Search Breadth & $\begin{array}{l}0.688^{*} \\
(0.286)\end{array}$ & $\begin{array}{l}0.562^{*} \\
(0.241)\end{array}$ & $\begin{array}{l}0.737^{*} \\
(0.317)\end{array}$ \\
\hline $\begin{array}{l}\text { Log Work } \\
\text { Experience }\end{array}$ & $\begin{array}{l}-0.497 \\
(0.396)\end{array}$ & $\begin{array}{l}-0.239 \\
(0.526)\end{array}$ & $\begin{array}{l}-0.600 \\
(0.396)\end{array}$ \\
\hline Consulting & $\begin{array}{c}0.466 \\
(0.428)\end{array}$ & $\begin{array}{l}0.156 \\
(0.411)\end{array}$ & $\begin{array}{l}0.635 \\
(0.505)\end{array}$ \\
\hline Energy & $\begin{array}{l}-0.343 \\
(0.529)\end{array}$ & $\begin{array}{l}-0.944 \\
(0.581)\end{array}$ & $\begin{array}{l}-0.0696 \\
(0.623)\end{array}$ \\
\hline Financial Services & $\begin{array}{c}0.640 \\
(0.482)\end{array}$ & $\begin{array}{c}0.173 \\
(0.482)\end{array}$ & $\begin{array}{c}0.849 \\
(0.557)\end{array}$ \\
\hline Government & $\begin{array}{c}0.959 \\
(0.640)\end{array}$ & $\begin{array}{l}-0.0900 \\
(0.773)\end{array}$ & $\begin{array}{l}1.334^{+} \\
(0.693)\end{array}$ \\
\hline Manufacturing & $\begin{array}{l}0.728^{*} \\
(0.364)\end{array}$ & $\begin{array}{c}0.476 \\
(0.429)\end{array}$ & $\begin{array}{l}0.857^{*} \\
(0.398)\end{array}$ \\
\hline $\begin{array}{l}\text { Media, Sports, } \\
\text { Entertainment }\end{array}$ & $\begin{array}{c}0.818 \\
(0.615)\end{array}$ & $\begin{array}{c}0.700 \\
(0.661)\end{array}$ & $\begin{array}{c}0.907 \\
(0.781)\end{array}$ \\
\hline $\begin{array}{l}\text { Pharma, Biotech, } \\
\text { Healthcare }\end{array}$ & $\begin{array}{c}0.888 \\
(0.546)\end{array}$ & $\begin{array}{c}0.688 \\
(0.565)\end{array}$ & $\begin{array}{l}0.995 \\
(0.679)\end{array}$ \\
\hline Real Estate & $\begin{array}{l}1.903 \\
(1.234)\end{array}$ & $\begin{array}{c}0.110 \\
(1.236)\end{array}$ & $\begin{array}{l}2.428^{+} \\
(1.283)\end{array}$ \\
\hline Retail & $\begin{array}{c}0.771 \\
(0.535)\end{array}$ & $\begin{array}{c}0.716 \\
(0.495)\end{array}$ & $\begin{array}{c}0.785 \\
(0.619)\end{array}$ \\
\hline Technology & $\begin{array}{c}0.588 \\
(0.502)\end{array}$ & $\begin{array}{c}0.476 \\
(0.494) \\
\end{array}$ & $\begin{array}{c}0.666 \\
(0.575) \\
\end{array}$ \\
\hline Constant & $\begin{array}{c}0.594 \\
(0.946)\end{array}$ & $\begin{array}{c}-1.683 \\
(1.027)\end{array}$ & $\begin{array}{c}0.601 \\
(1.030)\end{array}$ \\
\hline Observations & 214 & 214 & 214 \\
\hline
\end{tabular}

Standard errors in parentheses

${ }^{+} p<.10,{ }^{*} p<.05,{ }^{* *} p<.01,{ }^{* * *} p<.001$ 
Table A1-3. Random effects linear probability models with errors clustered by student predicting the level of help a student received as a function of the student's and the alum's gender.

\begin{tabular}{|c|c|c|c|c|c|c|c|c|c|}
\hline DV: & $\begin{array}{l}(6) \\
\text { Any } \\
\text { Help }\end{array}$ & $\begin{array}{c}(7) \\
\text { Costly } \\
\text { Help }\end{array}$ & $\begin{array}{c}\text { (8) } \\
\text { Referral }\end{array}$ & $\begin{array}{l}\text { (9) } \\
\text { Any } \\
\text { Help }\end{array}$ & $\begin{array}{l}\text { (10) } \\
\text { Costly } \\
\text { Help }\end{array}$ & $\begin{array}{c}\text { (11) } \\
\text { Referral }\end{array}$ & $\begin{array}{l}\text { (12) } \\
\text { Any } \\
\text { Help }\end{array}$ & $\begin{array}{l}\text { (13) } \\
\text { Costly } \\
\text { Help }\end{array}$ & $\begin{array}{c}\text { (14) } \\
\text { Referral }\end{array}$ \\
\hline Female Student & $\begin{array}{l}-0.0184 \\
(0.0398)\end{array}$ & $\begin{array}{c}0.0283 \\
(0.0514)\end{array}$ & $\begin{array}{l}-0.00462 \\
(0.0173)\end{array}$ & $\begin{array}{l}-0.0111 \\
(0.0397)\end{array}$ & $\begin{array}{c}0.0242 \\
(0.0511)\end{array}$ & $\begin{array}{l}-0.00398 \\
(0.0171)\end{array}$ & $\begin{array}{l}-0.0244 \\
(0.0421)\end{array}$ & $\begin{array}{c}0.0458 \\
(0.0577)\end{array}$ & $\begin{array}{l}-0.0128 \\
(0.0176)\end{array}$ \\
\hline Female Alum & & & & $\begin{array}{l}-0.0679^{*} \\
(0.0342)\end{array}$ & $\begin{array}{l}-0.00235 \\
(0.0376)\end{array}$ & $\begin{array}{l}-0.00324 \\
(0.0158)\end{array}$ & $\begin{array}{l}-0.0845^{+} \\
(0.0438)\end{array}$ & $\begin{array}{c}0.0243 \\
(0.0488)\end{array}$ & $\begin{array}{l}-0.0138 \\
(0.0196)\end{array}$ \\
\hline $\begin{array}{l}\text { Female Student } \\
\times \text { Female Alum }\end{array}$ & & & & & & & $\begin{array}{c}0.0471 \\
(0.0679)\end{array}$ & $\begin{array}{l}-0.0762 \\
(0.0764)\end{array}$ & $\begin{array}{c}0.0306 \\
(0.0338)\end{array}$ \\
\hline Asian & $\begin{array}{c}0.0207 \\
(0.0423)\end{array}$ & $\begin{array}{c}0.0301 \\
(0.0651)\end{array}$ & $\begin{array}{l}-0.0281 \\
(0.0239)\end{array}$ & $\begin{array}{c}0.0249 \\
(0.0424)\end{array}$ & $\begin{array}{c}0.0325 \\
(0.0652)\end{array}$ & $\begin{array}{l}-0.0281 \\
(0.0239)\end{array}$ & $\begin{array}{c}0.0251 \\
(0.0426)\end{array}$ & $\begin{array}{c}0.0328 \\
(0.0655)\end{array}$ & $\begin{array}{l}-0.0281 \\
(0.0237)\end{array}$ \\
\hline Other & $\begin{array}{c}0.0208 \\
(0.0740)\end{array}$ & $\begin{array}{c}0.0713 \\
(0.0893)\end{array}$ & $\begin{array}{l}-0.0420 \\
(0.0256)\end{array}$ & $\begin{array}{c}0.0221 \\
(0.0736)\end{array}$ & $\begin{array}{c}0.0726 \\
(0.0893)\end{array}$ & $\begin{array}{l}-0.0422^{+} \\
(0.0256)\end{array}$ & $\begin{array}{c}0.0247 \\
(0.0746)\end{array}$ & $\begin{array}{c}0.0701 \\
(0.0895)\end{array}$ & $\begin{array}{l}-0.0409 \\
(0.0253)\end{array}$ \\
\hline GMAT (std) & $\begin{array}{c}-0.00614 \\
(0.0139)\end{array}$ & $\begin{array}{l}-0.0151 \\
(0.0229)\end{array}$ & $\begin{array}{c}0.00447 \\
(0.00619)\end{array}$ & $\begin{array}{l}-0.00755 \\
(0.0140)\end{array}$ & $\begin{array}{l}-0.0157 \\
(0.0229)\end{array}$ & $\begin{array}{c}0.00444 \\
(0.00624)\end{array}$ & $\begin{array}{l}-0.00684 \\
(0.0140)\end{array}$ & $\begin{array}{l}-0.0169 \\
(0.0232)\end{array}$ & $\begin{array}{c}0.00485 \\
(0.00642)\end{array}$ \\
\hline Sponsored & $\begin{array}{l}0.0623^{+} \\
(0.0355)\end{array}$ & $\begin{array}{l}-0.0678 \\
(0.119)\end{array}$ & $\begin{array}{l}-0.0526^{* *} \\
(0.0176)\end{array}$ & $\begin{array}{l}0.0679^{+} \\
(0.0357)\end{array}$ & $\begin{array}{l}-0.0669 \\
(0.119)\end{array}$ & $\begin{array}{l}-0.0524^{* *} \\
(0.0173)\end{array}$ & $\begin{array}{l}0.0669^{+} \\
(0.0356)\end{array}$ & $\begin{array}{l}-0.0642 \\
(0.120)\end{array}$ & $\begin{array}{l}-0.0530^{* * *} \\
(0.0173)\end{array}$ \\
\hline $\begin{array}{l}\text { Native English } \\
\text { Speaker }\end{array}$ & $\begin{array}{l}0.0889^{+} \\
(0.0494)\end{array}$ & $\begin{array}{l}-0.0103 \\
(0.0592)\end{array}$ & $\begin{array}{l}-0.0400 \\
(0.0266)\end{array}$ & $\begin{array}{l}0.0885^{+} \\
(0.0497)\end{array}$ & $\begin{array}{l}-0.0107 \\
(0.0592)\end{array}$ & $\begin{array}{l}-0.0401 \\
(0.0266)\end{array}$ & $\begin{array}{l}0.0871^{+} \\
(0.0497)\end{array}$ & $\begin{array}{l}-0.00772 \\
(0.0601)\end{array}$ & $\begin{array}{l}-0.0413 \\
(0.0267)\end{array}$ \\
\hline Extraversion & $\begin{array}{c}0.0143 \\
(0.0168)\end{array}$ & $\begin{array}{l}0.0667^{* * *} \\
(0.0250)\end{array}$ & $\begin{array}{c}0.0175^{*} \\
(0.00841)\end{array}$ & $\begin{array}{c}0.0143 \\
(0.0168)\end{array}$ & $\begin{array}{l}0.0668^{* *} \\
(0.0250)\end{array}$ & $\begin{array}{c}0.0175^{*} \\
(0.00841)\end{array}$ & $\begin{array}{c}0.0136 \\
(0.0167)\end{array}$ & $\begin{array}{l}0.0678^{* *} \\
(0.0252)\end{array}$ & $\begin{array}{c}0.0171^{*} \\
(0.00823)\end{array}$ \\
\hline Search Breadth & $\begin{array}{l}0.00230 \\
(0.0282)\end{array}$ & $\begin{array}{c}0.0121 \\
(0.0491)\end{array}$ & $\begin{array}{l}-0.0150 \\
(0.0139)\end{array}$ & $\begin{array}{l}0.00650 \\
(0.0284)\end{array}$ & $\begin{array}{c}0.0138 \\
(0.0489)\end{array}$ & $\begin{array}{l}-0.0149 \\
(0.0140)\end{array}$ & $\begin{array}{l}0.00876 \\
(0.0281)\end{array}$ & $\begin{array}{c}0.0101 \\
(0.0495)\end{array}$ & $\begin{array}{l}-0.0134 \\
(0.0142)\end{array}$ \\
\hline $\begin{array}{l}\text { Log Work } \\
\text { Experience }\end{array}$ & $\begin{array}{l}-0.0586 \\
(0.0555)\end{array}$ & $\begin{array}{l}-0.143^{+} \\
(0.0785)\end{array}$ & $\begin{array}{c}0.0126 \\
(0.0502)\end{array}$ & $\begin{array}{l}-0.0546 \\
(0.0542)\end{array}$ & $\begin{array}{l}-0.145^{+} \\
(0.0786)\end{array}$ & $\begin{array}{c}0.0129 \\
(0.0502)\end{array}$ & $\begin{array}{l}-0.0527 \\
(0.0543)\end{array}$ & $\begin{array}{l}-0.148^{+} \\
(0.0795)\end{array}$ & $\begin{array}{c}0.0140 \\
(0.0502)\end{array}$ \\
\hline Constant & $\begin{array}{c}0.887^{* * * *} \\
(0.136) \\
\end{array}$ & $\begin{array}{c}0.255 \\
(0.186) \\
\end{array}$ & $\begin{array}{l}-0.00503 \\
(0.0946) \\
\end{array}$ & $\begin{array}{c}0.893^{* * * *} \\
(0.135) \\
\end{array}$ & $\begin{array}{c}0.258 \\
(0.186) \\
\end{array}$ & $\begin{array}{l}-0.00482 \\
(0.0946)\end{array}$ & $\begin{array}{c}0.895^{* * *} \\
(0.134) \\
\end{array}$ & $\begin{array}{c}0.252 \\
(0.188) \\
\end{array}$ & $\begin{array}{r}-0.00281 \\
(0.0937) \\
\end{array}$ \\
\hline Observations & 580 & 580 & 580 & 579 & 579 & 579 & 579 & 579 & 579 \\
\hline
\end{tabular}

Standard errors in parentheses

${ }^{+} p<.10,{ }^{*} p<.05,{ }^{* *} p<.01,{ }^{* * *} p<.001$

Note: Students were asked about the following types of help: "provided general career advice," "provided general advice about how to find an internship," "informed me about a job opening", "gave feedback on my resume, cover letter, etc.," "introduced me to his/her contacts, "put in a good word for me at his/her company", "acted as a formal referrer for me". We coded these outcomes using three dummy variables, representing different levels of help: Any Help was coded as 1 if the student reported receiving any type of help and 0 if the student indicated that the alum did not provide help of any type; Costly Help was coded as 1 if the student received an "introduction," a "good word," or a "referral" and as 0 otherwise; and Referral was coded as 1 if the student received a specific job referral and 0 otherwise. Note that Costly Help and Referral both imply that the alum was willing to put his or her own reputation on the line for the student; as such, these are potentially costlier for the contact. 
Table A1-4. Results of models that add the Bem (1974) Sex Role Inventory (BSRI) Femininity and Masculinity Indices (Models 1-3), along with their interactions with biological sex (Models 4-6).

\begin{tabular}{|c|c|c|c|c|c|c|}
\hline & $\begin{array}{c}(1) \\
\text { emailclick }\end{array}$ & $\begin{array}{c}(2) \\
\text { emailclick_f }\end{array}$ & $\begin{array}{c}\text { (3) } \\
\text { emailclick_m }\end{array}$ & $\begin{array}{c}(4) \\
\text { emailclick }\end{array}$ & $\begin{array}{c}\text { (5) } \\
\text { emailclick_f }\end{array}$ & $\begin{array}{c}\mathbf{6}) \\
\text { emailclick_m }\end{array}$ \\
\hline Female & $\begin{array}{l}0.419^{*} \\
(0.170)\end{array}$ & $\begin{array}{c}0.852^{* * *} \\
(0.186)\end{array}$ & $\begin{array}{c}0.241 \\
(0.192)\end{array}$ & $\begin{array}{l}-2.495 \\
(1.801)\end{array}$ & $\begin{array}{l}-2.727 \\
(2.018)\end{array}$ & $\begin{array}{l}-2.462 \\
(1.882)\end{array}$ \\
\hline \multirow[t]{2}{*}{ Asian } & 0.0518 & 0.211 & -0.0230 & 0.0718 & 0.233 & -0.00393 \\
\hline & $(0.291)$ & $(0.307)$ & $(0.332)$ & $(0.293)$ & $(0.309)$ & $(0.337)$ \\
\hline \multirow[t]{2}{*}{ Other } & $-0.579^{+}$ & -0.337 & $-0.657^{+}$ & $-0.555^{+}$ & -0.309 & $-0.634^{+}$ \\
\hline & $(0.316)$ & $(0.333)$ & $(0.347)$ & $(0.301)$ & $(0.341)$ & $(0.328)$ \\
\hline \multirow[t]{2}{*}{ GMAT (std) } & 0.0235 & -0.0677 & 0.0713 & 0.00180 & -0.0947 & 0.0517 \\
\hline & $(0.0810)$ & $(0.0711)$ & $(0.102)$ & $(0.0845)$ & $(0.0745)$ & $(0.110)$ \\
\hline \multirow[t]{2}{*}{ Sponsored } & $-1.977^{* *}$ & $-1.126^{*}$ & $-2.758^{* *}$ & $-1.874^{* *}$ & $-0.982^{*}$ & $-2.672^{* *}$ \\
\hline & $(0.653)$ & $(0.478)$ & $(0.984)$ & $(0.652)$ & $(0.471)$ & $(0.976)$ \\
\hline \multirow[t]{2}{*}{ Native English Speaker } & $-0.606^{+}$ & -0.206 & $-0.761^{*}$ & -0.528 & -0.104 & $-0.692^{+}$ \\
\hline & $(0.311)$ & $(0.292)$ & $(0.365)$ & $(0.336)$ & $(0.311)$ & $(0.394)$ \\
\hline \multirow[t]{2}{*}{ Extraversion } & $0.267^{+}$ & $0.388^{*}$ & 0.221 & 0.250 & $0.374^{*}$ & 0.204 \\
\hline & $(0.152)$ & $(0.158)$ & $(0.166)$ & $(0.156)$ & $(0.154)$ & $(0.173)$ \\
\hline \multirow[t]{2}{*}{ Search Breadth } & $0.589^{*}$ & $0.534^{*}$ & $0.607^{*}$ & $0.591^{*}$ & $0.534^{*}$ & $0.609^{*}$ \\
\hline & $(0.241)$ & $(0.216)$ & $(0.273)$ & $(0.235)$ & $(0.208)$ & $(0.267)$ \\
\hline \multirow[t]{2}{*}{ Log Work Experience } & -0.0130 & 0.0765 & -0.0490 & -0.0102 & 0.0749 & -0.0458 \\
\hline & $(0.236)$ & $(0.336)$ & $(0.231)$ & $(0.249)$ & $(0.343)$ & $(0.244)$ \\
\hline \multirow[t]{2}{*}{ BSR } & 0.152 & 0.0515 & 0.176 & 0.220 & 0.135 & 0.240 \\
\hline & $(0.249)$ & $(0.211)$ & $(0.279)$ & $(0.320)$ & $(0.287)$ & $(0.336)$ \\
\hline \multirow[t]{2}{*}{ BSRI Masculinity } & -0.315 & -0.174 & -0.352 & $-0.543^{+}$ & $-0.540^{*}$ & $-0.539^{+}$ \\
\hline & $(0.251)$ & $(0.250)$ & $(0.272)$ & $(0.289)$ & $(0.266)$ & $(0.315)$ \\
\hline \multirow{3}{*}{$\begin{array}{l}\text { BSRI Fem } \times \text { Female } \\
\text { BSRI Masc } \times \text { Female }\end{array}$} & & & & $\begin{array}{l}-0.316 \\
(0.474)\end{array}$ & $\begin{array}{l}-0.321 \\
(0.430)\end{array}$ & $\begin{array}{l}-0.320 \\
(0.555)\end{array}$ \\
\hline & & & & 0.881 & $1.020^{+}$ & 0.842 \\
\hline & & & & $(0.600)$ & $(0.555)$ & $(0.690)$ \\
\hline Constant & $\begin{array}{c}1.519 \\
(1.455)\end{array}$ & $\begin{array}{l}-1.058 \\
(1.416)\end{array}$ & $\begin{array}{l}1.650 \\
(1.556)\end{array}$ & $\begin{array}{c}2.300 \\
(1.482)\end{array}$ & $\begin{array}{c}0.305 \\
(1.310)\end{array}$ & $\begin{array}{c}2.263 \\
(1.582)\end{array}$ \\
\hline Observations & 256 & 256 & 256 & 256 & 256 & 256 \\
\hline
\end{tabular}

Standard errors in parentheses

${ }^{+} p<.10,{ }^{*} p<.05,{ }^{* * *} p<.01,{ }^{* * *} p<.001$ 


\section{APPENDIX 2: INTERVIEW GUIDES FOR STUDY 2}

\section{Appendix A2-1: Interview Guide for Round 1 Interviews}

\section{Demographics}

What are your [University] class year / gender / age / marital status / prior job?

What industry / industries did you recruit for? Did you recruit with the intention of potentially returning full time?

\section{Overview}

Thinking back to your internship recruiting experience as a first-year, in evaluating potential internships, what were the primary ways through which you gathered information?

(While we will not prompt this, pay close attention to see if "networking" is listed as an answer.)

- (If networking is mentioned) Did you use the [University] network?

- (If networking is NOT mentioned) Did you use networking as a way to assess and gather information?

What did you hope to get out of networking? (Do not prompt, but answers could include "a recommendation," "a sense of fit," etc.)

- How important was assessing your "fit" in an organization?

- How did you assess whether you would "fit" in an organization?

What kinds of questions did you prepare for a typical networking conversation?

Talk about 2-3 specific experiences you had with alumni during your networking process

- Tell us about the alum (industry, rank, gender, how you found them, etc.)

- What was your purpose when reaching out to this alum?

- What types of questions did you have for this alum? (firm fit vs career advice vs advocacy, etc.)

- What would you say was the most valuable for you from interacting with this alum?

- Before your conversation, did you feel like you would "fit in" in this alum's company? What about after the conversation? Why? 


\section{Appendix A2-2: Interview Guide for Round 2 Interviews}

Tell me about a time when you reached out to a female [University] alum who was particularly helpful?

Let them talk; possible follow up prompts:

- What did you talk about?

- Why was it so helpful?

- How did interaction with her shape your job search strategy?

- Why did you choose to reach out to this person in the first place?

(Repeat the same question about another female [University] alum who was particularly helpful

Like you said earlier [if applicable], it was important for you to talk to other women. Tell me about experiences you had that made you think it is important to reach out to female alums? (Or how did you figure this out?)

In networking with alumni, were there things you might have discussed with other women that you might not have discussed men? Are there topics that you were concerned about in your job search that you don't think men generally worried about?

Tell me what kind of guidance or tips did [University] or the career services office give you for networking while female? Is there, for example, a workshop on networking for women or anything like that? If so, what was covered?

Finally, some research suggests that women reach out to more female alumni than men do. Does that seem consistent with your experience? If it is true, why do you think that may be?

Is there anything else that seems relevant that I haven't asked about? 